\title{
New crustose Teloschistaceae in Central Europe
}

\section{Jan VONDRÁK, Ivan FROLOV, Pavel ŘÍHA, Pavel HROUZEK, Zdeněk PALICE, Olga NADYEINA, Gökhan HALICI, Alexander KHODOSOVTSEV and Claude ROUX}

\begin{abstract}
Central Europe in general is poor in Teloschistaceae lichen crusts (Caloplaca s. lat.). Diversity of these lichens is increased by the occurrence of some Arctic, Mediterranean and continental species, which are here close to the limits of their range. Examples include:

1) Caloplaca interfulgens, previously known from arid territories of northern Africa and western Asia, is recorded, surprisingly, from Austria, Czech Republic, Germany, Slovakia and southern Russia. In Central Europe, it is restricted to scattered xerothermic limestone outcrops.

2) Caloplaca scabrosa, previously known only from Svalbard, is recorded from the Sudetes in the Czech Republic. It is similar to, but not conspecific with, C. furfuracea. Its diagnostic characters include a blastidiate thallus and the presence of atranorin. Our results show that atranorin is absent in the majority of taxa related to $C$. furfuracea with only two exceptions: the sample from Eastern Carpathians, here called $C$. aff. scabrosa, and in one Sudetan sample identified as $C$. crenularia.

3) Caloplaca emilii, newly described below, is closely related to the Mediterranean C. areolata. We consider C. emilii a Mediterranean species rarely occurring in higher latitudes in Austria, the Czech Republic and Germany. It is distinguished from $C$. areolata mainly by the presence of vegetative diaspores (blastidia); a possible role of blastidia in the distribution pattern of $C$. emilii is discussed below. Status of the names Caloplaca areolata, $C$. isidiigera and $C$. spalatensisis, formerly used for the new taxon, is clarified.

4) Caloplaca molariformis, newly described below, belongs to the Pyrenodesmia group (a lineage of Caloplaca without anthraquinones). It is a continental species, frequently collected on limestone or lime-rich tuffs in steppes or deserts in Turkey, Iran, western Kazakhstan and southern Russia, and is also known from eastern Ukraine and southern Slovakia. Caloplaca molariformis is characterized by its thick thallus with fungal and algal tissues arranged in high stacks.

5) Caloplaca substerilis, newly described below, is distinguished from the closely related C. ulcerosa by its endophloeodal or minutely squamulose thallus with soralia formed in bark crevices or on margins of squamules. While $C$. ulcerosa has a maritime distribution in Europe, C. substerilis is typically a continental species. North American continental lichens called "C. ulcerosa" are phylogenetically closer and more similar to $C$. substerilis.

The positions within Teloschistaceae of the taxa considered are demonstrated by ITS phylogenies. The distributions of $C$. areolata, $C$. emilii and $C$. interfulgens are mapped. The new species are fully described using more than a hundred phenotype characters, and diagnostic characters are indicated separately.
\end{abstract}

Key words: biodiversity, biogeography, ITS phylogeny, lichen phenotype evaluation, species recognition, vegetative reproduction

Accepted for publication 26 May 2013

J. Vondrák: Institute of Botany, Academy of Sciences, Zámek 1, Průhonice, CZ-25243, Czech Republic; Department of Botany, Faculty of Science, University of South Bohemia, Branišovská 31, České Budějovice, CZ370 05, Czech Republic. Email: j.vondrak@seznam.cz I. Frolov: Faculty of Science, University of South Bohemia, Branišovská 31, České Budějovice, CZ-370 05, Czech Republic; Faculty of Biology, Ural Federal University, ul. Mira 19, Ekaterinburg, 620002, Russia.

P. Ŕíha: Department of Botany, Faculty of Science, University of South Bohemia, Branišovská 31, České Budějovice, CZ-370 05, Czech Republic.

P. Hrouzek: Department of Autotrophic Microorganisms, Institute of Microbiology, Academy of Sciences, Opatovický mlýn, Třeboň, CZ-379 81, Czech Republic. Z. Palice: Institute of Botany, Academy of Sciences,
Zámek 1, Průhonice, CZ-25243, Czech Republic; Department of Botany, Faculty of Natural Sciences, Charles University, Benátská 2, Praha, CZ-128 01, Czech Republic.

O. Nadyeina: Department of Lichenology and Bryology, M.G. Kholodny Institute of Botany, National Academy of Sciences of Ukraine, Tereschenkivska str. 2, 01601 Kiev, Ukraine; Biodiversity and Conservation Biology Swiss Federal Institute for Forest, Snow and Landscape Research, WSL Zürcherstr. 111, CH-8903, Birmensdorf, Switzerland.

G. Halıc1: Erciyes University, Faculty of Science, Department of Biology, 38039, Kayseri, Turkey.

A. Khodosovtsev: Kherson State University, 40 Rokiv Zhovtnya str. 27, 73000 Kherson, Ukraine.

C. Roux: Chemin des Vignes-Vieilles, FR-84120, Mirabeau, France. 


\section{Introduction}

Teloschistaceae, with its 1000 or more species (Arup et al. 2013), has highest biodiversity in temperate regions (Feuerer 2011). In Central Europe, hot spots of Caloplaca diversity are restricted to habitats with sun-exposed calcareous or base-rich siliceous outcrops in alpine zones of the Alps and high Carpathians (e.g. Poelt 1953a, b, 1954, 1955, 1960, 1964; Wilk \& Flakus 2006; Vondrák et al. 2008), or in dry and warm rocky steppes (e.g. Poelt 1975; Vondrák et al. 2007). In other Central European habitats, only the common epiphytic and epilithic species are found; the highest number of these common species is found on lime-rich artificial substrata (e.g. Vondrák \& Hrouzek 2006; Svoboda et al. 2007; Vondrák et al. 2010a).

Altogether, more than one hundred Caloplaca species occur in Central Europe (Vondrák \& Wirth 2013), but about two thirds of these are rare species, known from very few localities. In other words, the generally low Caloplaca species diversity in Central Europe is partly enriched by marginal occurrences of some 'exotic' taxa further distributed in the Mediterranean basin, western Asia or in the Arctic. Known examples are $C$. exsecuta (Nyl.) Dalla Torre \& Sarnth., C. haematites (Chaub.) Zwackh, C. pollinii (A. Massal.) Jatta (Vondrák \& Wirth 2013), C. raesaenenii Bredkina (e.g. Søchting \& Stordeur 2001), C. tominii Savicz (Vondrák et al. 2011), and many others.

Here we report several taxa newly discovered in Central Europe. Caloplaca interfulgens and $C$. scabrosa were previously known only from very distant areas and their occurrence in Central Europe was not expected. Caloplaca emilii, C. molariformis and C. substerilis are newly described from elsewhere, but also occur in Central Europe.

\section{Materials and Methods}

\section{Sampling}

Lichen samples were collected by the authors from various European and Asian localities between 1994 and 2012. We list information regarding locality, habitat, collection and deposition of specimens. Citations of the older herbarium samples from BRA and STU (in Caloplaca interfulgens and C. emilii) are as complete as we can make them. Specimens from CBFS, PRA and GZU used for comparative studies are cited more briefly in the text.

\section{Phenotype evaluation}

More than 100 phenotype characters were assessed before preparing descriptions of the three new taxa. The list of characters and the way in which they were studied is provided in Vondrák et al. (2013). All observations were carried out on dead, stabilized material, on handcut sections mounted in water, without any chemical treatments. Measurements are accurate to $0.5 \mu \mathrm{m}$ for cells and $10 \mu \mathrm{m}$ for larger structures. All measurements of cells include their walls, except for tissues with glutinized cell walls. In Caloplaca molariformis, the widths of algal and fungal stacks are measured at the mid-point of their vertical extent. In each sample, ten measurements were made for each measurable character. Results of the measurements are given as (min.-) $\overline{\mathrm{x}}_{1}-\bar{x}_{2}-\overline{\mathrm{x}}_{3}$ (-max.), where $\mathrm{min} / \mathrm{max}$ are extremes from all measurements, $\overline{\mathrm{x}}_{1}$ is the lowest specimen arithmetic mean observed, $\bar{x}_{2}$ is the arithmetic mean of all observations, $\overline{\mathrm{x}}_{3}$ is the highest specimen arithmetic mean observed. In cases where measurements were made from one sample, only $\bar{x}_{2}$ is recorded. Total number of measurements $(n)$, number of samples asessed $(\mathrm{N})$, and standard deviation from all measurements (SD) are given in square parenthesis for each character measured $[n ; \mathrm{N} ; \mathrm{SD}$ ]. General morphological terminology follows Smith et al. (2009); the term "alveolate cortex" is adopted from Vondrák $e t$ al. $(2009 a)$.

\section{Chemistry}

Spot tests with $\mathrm{KOH}(\mathrm{K})$, sodium hypochlorite (C), paraphenylenediamine $(\mathrm{P})$ and UV light were performed in each new species. Tissues were also tested for amyloidity by the reaction with Lugol's solution (I). Pigments insoluble in acetone were evaluated following Meyer \& Printzen (2000). Extracellular crystals were examined by the reaction with concentrated $\mathrm{H}_{2} \mathrm{SO}_{4}$ for detection of Ca. HPLC was used for identification of acetone-soluble compounds. The anthraquinone contents were analyzed on a LichroCART 250-4 RP18-e (5 $\mu \mathrm{m})$ column using an Agilent 1100 Series Chromatograph after Søchting (1997), but using the wavelength (240 $\mathrm{nm})$. Whole absorption spectra in the range 200-600 $\mathrm{nm}$ were monitored. The presence of atranorin in the samples was determined after Feige et al. (1993) on the same column and chromatographic system.

\section{DNA extraction, amplification and sequencing}

The simple $\mathrm{NaOH}$ extraction (Werner et al. 2002) was used for DNA isolations. Primers for PCR amplification were ITS1F (Gardes \& Bruns 1993) and ITS4 (White et al. 1990). PCR cycling parameters follow Ekman (2001). A total of 51 nuclear ITS sequences were newly generated (Table 1). 
TABLE 1. New Caloplaca ITS sequences generated during this study

Labels of phylogenetic tree terminals

Caloplaca aff. crenularia Canary Islands

C. areolata Croatia

C. areolata Montenegro

C. areolata Spain

C. crenularia Bulgaria

C. crenularia Crete 1

C. crenularia Crete 2

C. crenularia Hungary

C. crenularia Iran

C. crenularia Spain

C. crenularia Turkey

C. emilii Bulgaria, holotype

C. emilii Bulgaria, Rhodopes

C. emilii Czech Republic

C. emilii Czech Republic 2

C. emilii France

C. emilii Greece

C. ferrarii s.lat. Czech Republic 1

C. ferrarii s.lat. Czech Republic 2

C. ferrarii s.lat. Czech Republic 3

C. ferrarii s.lat. Czech Republic 4

C. furfuracea Austria

C. fuscorufa Ukraine

C. herbidella Turkey

C. interfulgens Czech Republic 1

C. interfulgens Czech Republic 2

C. interfulgens Czech Republic 3

C. interfulgens Czech Republic 4

C. interfulgens Czech Republic 5

C. interfulgens Slovakia 1

C. interfulgens Slovakia 2

C. interfulgens southern Russia

C. interfulgens Turkey

C. interfulgens Turkey

C. interfulgens Turkey

C. lactea Greece

C. lactea Italy

C. molariformis Kazakhstan

C. molariformis Slovakia, holotype

C. molariformis Turkey

C. molariformis Ukraine 1

C. molariformis Ukraine 2

C. scabrosa Czech Republic

C. "scabrosa" Ukraine 1

C. "scabrosa" Ukraine 2

C. substerilis Austria

C. substerilis Bulgaria

C. substerilis Czech Republic, holotype

C. substerilis Slovakia

C. "ulcerosa" USA

C. "ulcerosa" USA 2

C. sp. southern Russia
Voucher

GenBank

Accession No.

GZU (1993, Poelt E Sanchez-Pinto)

KC416116

CBFS JV7950

GZU (2008, Mayrhofer)

CBFS JV6314

CBFS JV2065

GZU (Mayrhofer 18045)

CBFS JV4137

CBFS JV6409

CBFS JV5608

CBFS JV6255

CBFS JV6064

CBFS JV6600

CBFS JV2223

CBFS JV9358

CBFS JV9357

Hb. Clauzade 23475

CBFS JV8832

CBFS JV8782

CBFS JV9150

CBFS JV9043

CBFS JV9151

PRA (Palice 12390)

CBFS JV6204

PRA (Palice 11832)

CBFS JV9399

CBFS JV9153

CBFS JV9156

CBFS JV9155

CBFS JV9144

CBFS JV9260

CBFS JV9186

CBFS JV9396

CBFS JV8552

CBFS JV8557

CBFS JV8539

CBFS JV8331

CBFS JV8679

CBFS JV7635

CBFS JV10192

CBFS JV9787

KV (Luhansk, Nadyeina 132)

KV (Luhansk, Nadyeina 134)

CBFS JV1908

CBFS JV6198

CBFS JV6199

CBFS JV7257

CBFS (Exs. of Caloplaca, nr 11)

CBFS JV7920

PRA (Palice 13441)

GZU (Wetmore 93230)

GZU (Advaita 4915)

CBFS JV8181
KC416098

KC416097

KC416096

KC416112

KC416113

KC416119

KC416117

KC416115

KC416114

KC416118

KC416101

KC416099

KC416102

KC416103

KC416100

KC416104

KC416139

KC416132

KC416137

KC416140

KC416120

KC416111

KC917268

KC416134

KC416131

KC416129

KC416130

KC416138

KC416136

KC416135

KC416133

KC416125

KC416126

KC416127

KC416128

KC416124

KC416146

KC416142

KC416144

KC416143

KC416145

KC416122

KC416121

KC416123

KC416107

KC416108

KC416109

KC416110

KC416105

KC416106

KC416141 
TABLE 2. Summary of phylogenetic analyses: length of alignments (including gapped positions) and model selected for the purpose of MrBayes calculation

\begin{tabular}{llll}
\hline Target Group & Phylogenetic tree & Length of alignment & Model \\
\hline Caloplaca crenulatella group & Fig. 2 & 525 positions & SYM+ADGamma \\
C. crenularia group & Fig. 3 & 486 positions & GTR+ADGamma \\
C. $x$ erica group & Fig. 4 & 501 positions & SYM+ADGamma \\
Pyrenodesmia group & Fig. 5 & 535 positions & SYM+ADGamma \\
C. ulceros and related taxa & Fig. 6 & 519 positions & GTR+ADGamma \\
\hline
\end{tabular}

\section{Phylogenetic analyses}

Five independent phylogenetic analyses of the nuclear ITS region were made to cover the individual groups studied. All analyses followed almost the same design; differences are listed in Table 2. Sequences were aligned using the MAFFT v6 server (http://mafft.cbrc.jp/alignment/server; Katoh \& Toh 2008) according to the LINS-i strategy. The resulting alignments required some manual adjustments (done in BioEdit; Hall 1999) and, in the case of the $C$. crenularia group, also trimming of unalignable positions (using TrimAl-automated 1 algorithm, Capella-Gutierrez et al. 2009). The length of datasets submitted to further analyses ranged from 486535 positions. Final alignments were submitted to TreeBase http://treebase.org/treebase-web/home.html.

Molecular phylogenies were estimated by Bayesian inference as incorporated in MrBayes 3.0b4 (Huelsenbeck \& Ronquist 2001; Ronquist \& Huelsenbeck 2003). Model selection was committed to the Kakusan4 algorithm (Tanabe 2011), whereas the baseml software (Adachi \& Hasegawa 1996) served as the computational core. With reference to the Bayesian information criterion (Schwartz 1978), we opted for SYM or GTR models with rate variation across sites simulated by discrete gamma distribution ( $\Gamma 8)$ and autocorrelated by the AdGamma rates prior (Table 2.). The increased probability of transitions over transversions, well documented in many rDNA datasets (see e.g. Keller et al. 2007), was reflected by setting the substitution rates prior (revMatPr) to dirichlet with values 1 and 3 for these two mutational types, respectively. Each analysis comprised two independent runs, each of which encompassed four Metropolis-coupled MCMC chains with 10000000 generations sampled after every 1000th generation. In every run, one Markov chain was cold and three were incrementally heated by the parameter of $0 \cdot 3$. To eliminate trees sampled before reaching apparent stationarity, the first $25 \%$ of entries were discarded as burn-in and the rest were used to compute majority-rule consensus, where the relative occurrences of nodes are identified with the Bayesian posterior probabilities (Figs 2-6). Bayesian posterior probabilities $\geq 50$ are shown, branches with lower posterior probabilities are collapsed.

\section{Nomenclature}

Arup et al. (2013) proposed a new nomenclature within Teloschistaceae and split the crustose genus Caloplaca into numerous genera. We do not follow the new nomencla- ture in this paper, because generic names are still missing for many Teloschistaceae taxa, including Caloplaca emilii and C. substerilis described here. Names of other lichen taxa follow the Index Fungorum http://www. indexfungorum.org/names/names.asp

\section{Records new to Central Europe}

\section{Caloplaca interfulgens (Nyl.) J. Steiner}

Verh. zool.-bot. Ges. Wien 52: 479 (902). - Lecanora interfulgens Nyl. Flora 56: 3401878.

Images of some Czech and German specimens are available on the lichenological web page at the University of South Bohemia http://botanika.bf.jcu.cz/lichenology/ index.php?pg $=5$.

Diagnostic characters. Thallus well-developed, consisting of yellow areoles and often with squamules at the margin. Ascospores polarilocular, c. 15-19 $\times 5 \cdot 0-7.5 \mu \mathrm{m}$ with septa up to $4 \mu \mathrm{m}$ wide. Prothallus indistinct. Occurs on calcareous rocks.

Similar taxa are Caloplaca crenulatella s. lat. (the yellow thallus usually reduced), $C$. diffusa Vondrák \& Llimona (on non-calcareous rocks, yellow thallus with thin diffuse margin, with grey-white prothallus, squamules absent) and species of the Caloplaca velana complex (ascospores shorter with thicker septa).

Distribution (Fig. 1A). Caloplaca interfulgens was previously known only from deserts, semi-deserts or steppes in North Africa (Nylander 1878; Navarro-Rosinés \& Hladun 1996), Mediterranean Europe (Italy: Nimis \& Martellos 2008; Spain: Nimis et al. 1998), Iran, Kazakhstan (Vondrák et al. 2011) and continental Turkey (Vondrák et al. 2012a). The new records are surprisingly from less arid territories in Austria, the Czech Republic, Germany, southern Russia and Slovakia. 

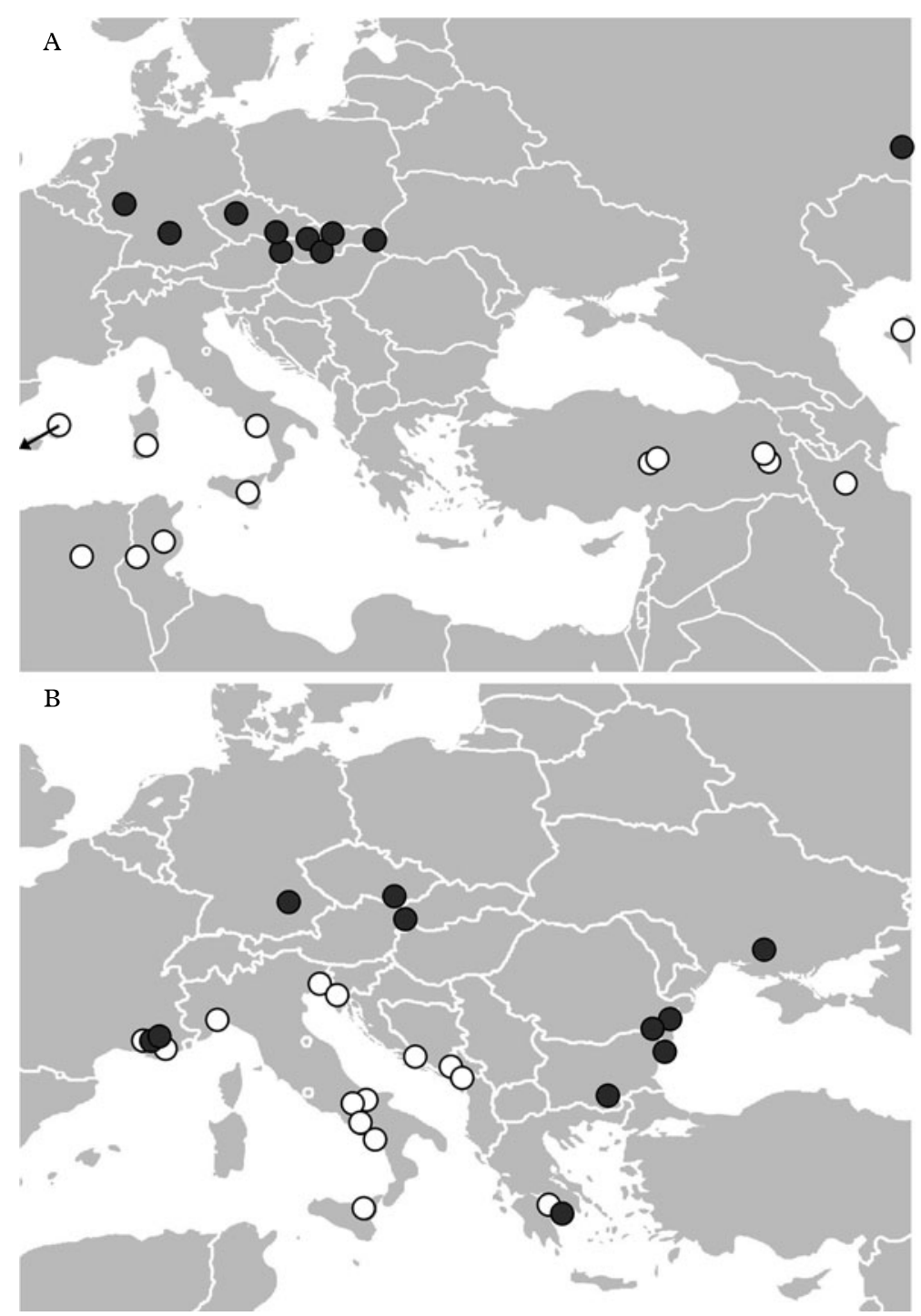

FIG. 1. Distribution maps. A, Caloplaca interfulgens, previously published data (white dots), new records (black dots); B, C. emilii (black dots), C. areolata (white dots).

In all Central European localities, $C$. interfulgens is restricted to limestone outcrops in xerothermic sites (often south-facing steppes).

Phylogeny. In the ITS phylogeny of the Caloplaca crenulatella group (Fig. 2), Caloplaca interfulgens forms a well-resolved sister clade to Caloplaca tominii, a sorediate species with a similar distribution pattern in Europe.
Taxonomic note. Although the Caloplaca crenulatella group has been studied recently (Navarro-Rosinés \& Hladun 1996; Vondrák et al. 2011), it is still poorly understood and many lineages are not yet well characterized. Fortunately, its well-developed areolate thallus separates $C$. interfulgens from the many taxa with reduced thalli. However, some Central Asian taxa have a thallus similar to 


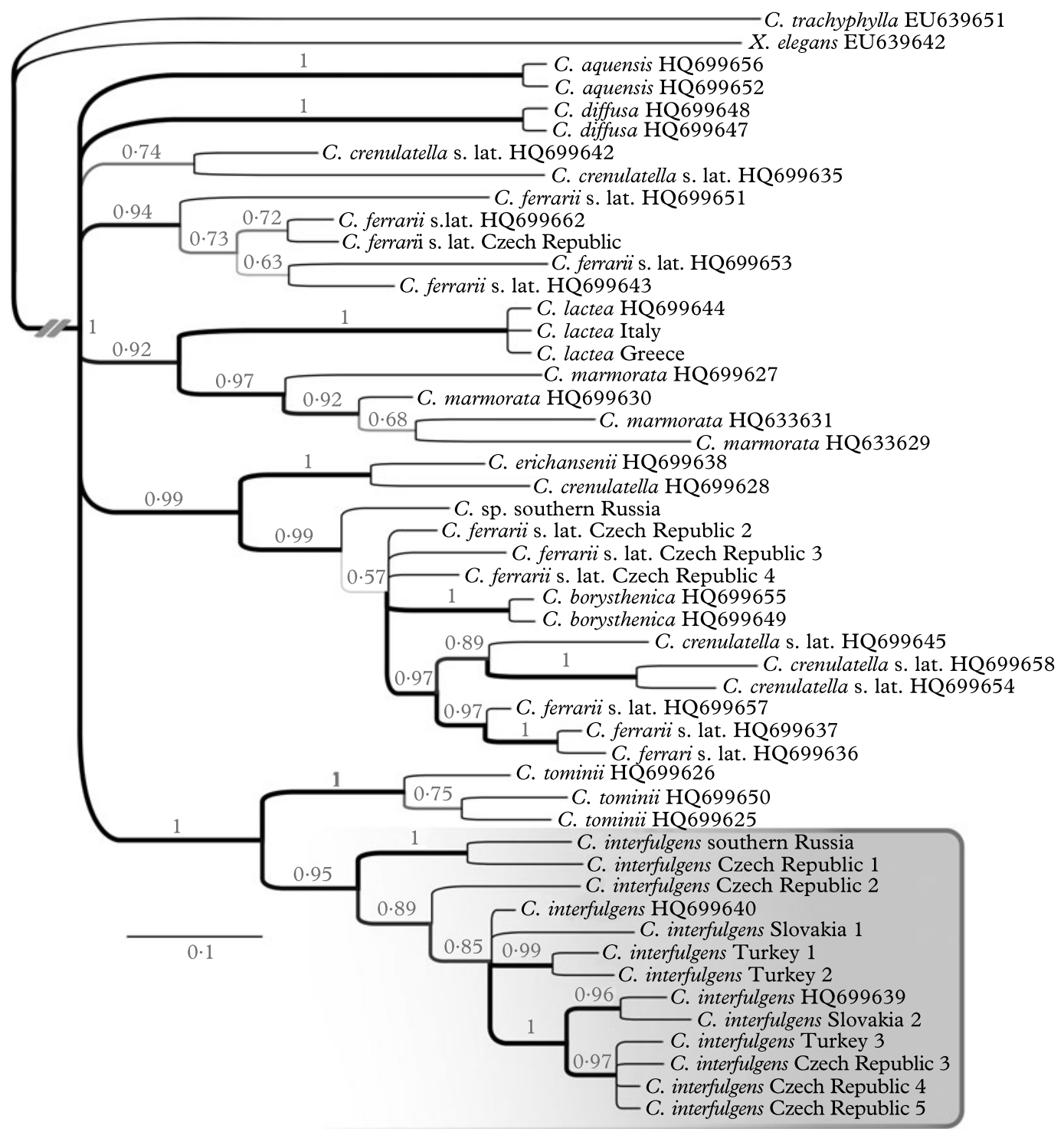

FIG. 2. Bayesian ITS phylogeny of the Caloplaca crenulatella group; C. interfulgens clade delimited by the grey square.

C. interfulgens (e.g. 'Caloplaca sp., southern Russia' in Fig. 2) and their delimitation requires further study.

New records. Austria: Niederösterreich: Wien, Hainburg an der Donau, rocks on SW slopes of hill Braunberg NE of town, $48^{\circ} 09^{\prime} 10^{\prime \prime} \mathrm{N}, 16^{\circ} 57^{\prime} 12^{\prime \prime} \mathrm{E}, 280 \mathrm{~m}$, 2012, F. Vondrák 9550 (CBFS).-Czech Republic: Central Bohemia: Bohemian karst, Beroun, Tmán̆, protected area Kotýz, $1.5 \mathrm{~km}$ NE of village, $49^{\circ} 54^{\prime} 56^{\prime \prime} \mathrm{N}$, $14^{\circ} 2^{\prime} 55^{\prime \prime} \mathrm{E}, 350 \mathrm{~m}, 2011$, f. Vondrák 9153, 9155 \& 9156 (CBFS); Praha, Dobřichovice, Karlík, limestone outcrops $1 \mathrm{~km} \mathrm{NW}$ of ruin of Karlík, $49^{\circ} 56^{\prime} 56^{\prime \prime} \mathrm{N}$, $14^{\circ} 14^{\prime} 49^{\prime \prime} \mathrm{E}, 300$ m, 2011, I. Frolov E F. Vondrák 9399 (CBFS); Praha, Radotín, Kosoř, protected area Černá rokle, E of village, $49^{\circ} 59^{\prime} 21^{\prime \prime} \mathrm{N}, 14^{\circ} 20^{\prime} 8^{\prime \prime} \mathrm{E}, 250-300$ m, 2011, Z. Palice E F. Vondrák 9144 (CBFS). Southern Moravia: Pavlovské vrchy hills, Mikulov, Klentnice, SE slope of hill Pálava, $48^{\circ} 51^{\prime} 22^{\prime \prime} \mathrm{N}, 16^{\circ} 38^{\prime} 33^{\prime \prime} \mathrm{E}, 350-400$ m, 2012, f. Vondrák 9577 (CBFS)._Germany: BadenWürttemberg: Schwäbishe Alb Mts, Langenau, Albeck, shallow valley W of Kornberghöfe, 520-550 m, 1984, V. Wirth 29418 (STU; hb. Wirth). Rheinland-Pfalz: Eifel Mts, Uxheim, Dreimühlen, limestone outcrops in dry 
grassland, 1992, V. Wirth 23937 E R. Düll (STU; hb. Wirth).-Russia: Orenburgskaya Oblast': surroundings of water reservoir "Iriklinskoe vodokhranilishche", vill. Chapaevka, limestone rocks on opposite slope of lake, $\mathrm{NE}$ of village, $52^{\circ} 05^{\prime} 12^{\prime \prime} \mathrm{N}, 58^{\circ} 48^{\prime} 1^{\prime \prime} \mathrm{E}, 270-290 \mathrm{~m}$, 2011, I. Frolov \& f. Vondrák 9396 (CBFS)._Slovakia: Cerová vrchovina upland: Filakovo, Hajnáčka, hill Ragač, lime-rich outcrop of volcanic pyroclastics in open beechoak forest, $48^{\circ} 13^{\prime} 25^{\prime \prime} \mathrm{N}, 19^{\circ} 59^{\prime} 6^{\prime \prime} \mathrm{E}, 500 \mathrm{~m}, 2012, \mathcal{F}$. Vondrák 10137 (CBFS). Muranská Planina Mts: Brezno, Tisovec, hill Okruhla skala, c. $2 \mathrm{~km} \mathrm{~W}$ of town, $48^{\circ} 40^{\prime} 42^{\prime \prime} \mathrm{N}, 19^{\circ} 54^{\prime} 57^{\prime \prime} \mathrm{E}$, c. $800 \mathrm{~m}, 2011$, f. Vondrák 9260 (CBFS). Strážovské vrchy Mts: Ilava, Zliechov, on S-slope of Mt Strážov, $48^{\circ} 56^{\prime} 59^{\prime \prime} \mathrm{N}, 18^{\circ} 27^{\prime} 16^{\prime \prime} \mathrm{E}, 1000$ m, 2012, f. Vondrák 10198 (CBFS). Vihorlat Mts: Sobrance, Podhorod [Podhradí], 1930, F. Buček (BRA, sub Caloplaca zimmermannii, Servít, nomen ined.).

\section{Caloplaca scabrosa Søchting, Lorentsen \& Arup}

Nova Hedwigia 87: 89 (2008).

Images of European samples and the isotype are available on the lichenological web at the University of South Bohemia http://botanika.bf.jcu.cz/lichenology/index. php?pg=5.

Observation of the type specimen. Isotype (CBFS JV9402, ex C; Søchting 5513) examined in detail.

Thallus rough and scabrous by blastidia, densely covering the thallus surface. Blastidia (40-)71(-130) $\mu \mathrm{m}$ diam. $[10 ; 1 ; 29]$. Thallus surface pale grey to sordid white, but tips of blastidia often dark grey. Grey thallus parts containing Cinereorufa-green (green-grey in water, $\mathrm{K}-, \mathrm{N}+\mathrm{red}$ ) in the uppermost thallus cells. Thallus divided into thin and more or less flat angular areoles, c. $0 \cdot 2-1 \cdot 3 \mathrm{~mm}$ diam. The real cortex absent, but indistinct alveolate cortex present in spots, of spherical, thick-walled cells (wall c. $1 \mu \mathrm{m}$ thick). Thallus without anthraquinones, but with atranorin.

Apothecia biatorine, deep red (old apothecia somewhat blackened), with anthraquinones; major: parietin and 7-Cl-emodin; traces of emodin, 7-Cl-citreorosein, 7-Clemodinal and parietinic acid (C+ purple owing to chlorinated compounds). True exciple of palisade prosoplectenchyma, of cells with glutinized, $c .1 \mu \mathrm{m}$ thick walls. Lower exciple and lower hypothecium brown-red (possibly due to small amount of anthraquinones; with weak $\mathrm{K}+$ purple reaction). Ascospores polarilocular, $\quad(12 \cdot 0-) 14 \cdot 0(-17 \cdot 0) \times(5 \cdot 5-) 6 \cdot 5(-8 \cdot 0)$ $\mu \mathrm{m}[10 ; 1 ; 1.3 \& 0.7]$, with septa (4.0-) $5 \cdot 0(-5 \cdot 5) \mu \mathrm{m}[10 ; 1 ; 0 \cdot 5]$.
Pycnidia not present on the available isotype material. The type material is also described in Søchting et al. (2008).

Observations of the Central European specimens. (Fig. 7A).

Thallus rough and scabrous by blastidia, densely covering the thallus surface. Blastidia (30-)58-67-72(-130) $\mu \mathrm{m}$ diam. [30; 3; 28]. Thallus surface pale grey to white, but tips of blastidia often dark grey. Grey pigmented thallus parts containing Cinereorufa-green (green-grey in water, $\mathrm{K}-, \mathrm{N}+$ red) in the uppermost thallus cells. Thallus divided into thin and flat angular areoles, c. $0 \cdot 2-1.0 \mathrm{~mm}$ diam. The real cortex absent, but indistinct alveolate cortex present in spots, of spherical, thick-walled cells (walls $c .1 \mu \mathrm{m}$ thick). Thallus without anthraquinones, but with atranorin.

Apothecia deep red (old blackened apothecia not observed), with anthraquinones; major: parietin and 7-Cl emodin; traces of emodin, fragilin and parietinic acid (C+ purple owing to chlorinated compounds); biatorine or zeorine; thalline exciple sometimes strongly expanded in old apothecia. True exciple of palisade prosoplectenchyma, of cells with glutinized, $1-2 \mu \mathrm{m}$ thick walls. Inner exciple and lower hypothecium brown-red (perhaps by anthraquinones). Ascospores polarilocular, $\quad(11.5-) 13.0(-15 \cdot 0) \times(6 \cdot 5-) 7.5$ $(-9.0) \mu \mathrm{m}[10 ; 1 ; 1.4 \& 0.8]$, with septa (3.0-) 4.0(-5.0) $\mu \mathrm{m}[10 ; 1 ; 0 \cdot 5]$.

Pycnidia with red tops, containing chlorinated anthraquinones (C+ purple). Conidia more or less bacilliform, c. 3-4 $1 \mu \mathrm{m}$.

Importance of particular characters. Caloplaca scabrosa shares many characters with other related taxa from the $C$. crenularia group (as defined in Fig. 3), so their diagnostic power is rather low. They include: 1) presence of Cinereorufa-green in the thallus; 2) apothecia with chlorinated anthraquinones (C+ purple); 3) structure of the true exciple; 4) brownish pigment in lower hypothecium and inner true exciple; 5) pycnidia with red caps.

Some characters are specific for $C$. scabrosa: 1) presence and size of blastidia; 2) presence of atranorin in the thallus. We have tested the diagnostic power of the presence 


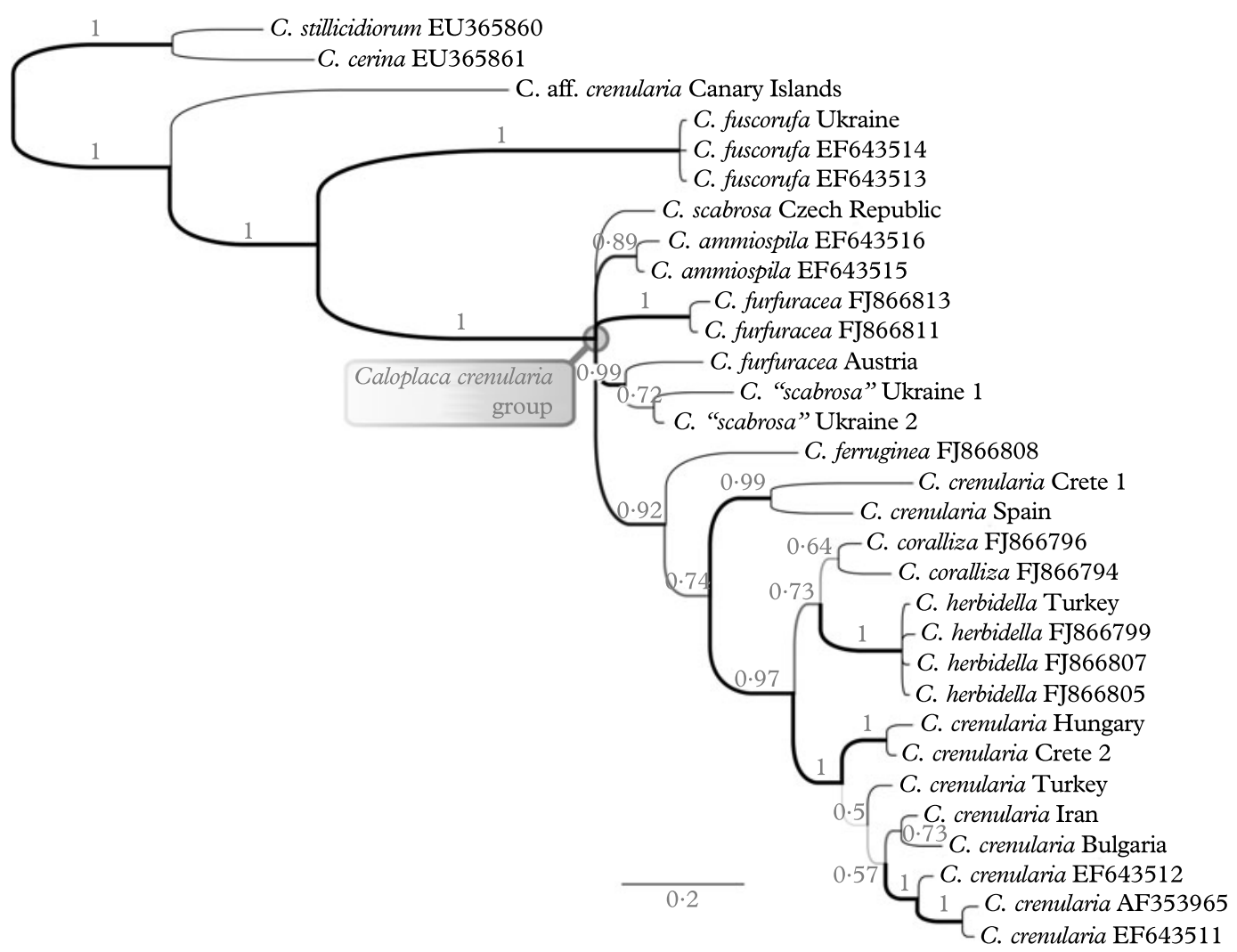

FIG. 3. Bayesian ITS phylogeny of the Caloplaca crenularia group including the Central European sample of C. scabrosa and C. "scabrosa" from the Eastern Carpathians.

of atranorin. We analyzed thalli of various species of the C. crenularia group: Caloplaca ammiospila (Ach.) H. Olivier (CBFS JV10223), C. crenularia (With.) J. R. Laundon (CBFS JV4596; 5608; hb. Z. Palice 7837; Poland, Nowak's exsiccate 203 in GZU; Sardinia, 1986, Poelt in GZU), C. ferruginea (Huds.) Th. Fr. (CBFS JV7224; 7256), C. furfuracea H. Magn. (Ural, hb. I. Frolov), and C. hungarica H. Magn. (CBFS JV3081). Atranorin was detected in only one sample of $C$. crenularia from the basalt outcrops in the Karkonosze Mountains, W Sudetes (Nowak, Lich. Polon. Exs. n. 203), indicating that this $C$. crenularia specimen does not belong in the main $C$. crenularia clade.

The type specimen of Caloplaca scabrosa differs from the Central European material in the following characters: 1) size of areoles;
2) thallus thickness; 3) extent of the thalline exciple. Based on our observations of numerous samples of the $C$. crenularia group, these characters were very variable both within and between specimens of a single species, so the differences are of little taxonomic importance. Ascospore size and septum width also differ between the type and the Central European collections, but this difference may be merely a consequence of the low number of available specimens and measurements.

Phylogeny. The ITS sequence of the Central European specimen of Caloplaca scabrosa is placed in the basal polytomy of the ITS phylogeny of the C. crenularia group (Fig. 3). It is perhaps closely related to the arcticalpine $C$. ammiospila or boreo-montane $C$. furfuracea. 
Taxonomic notes. The epixylic taxon Caloplaca furfuracea is very similar to C. scabrosa. It likewise produces blastidia (isidia according to Arup \& Ảkelius 2009) of the same size; tips of blastidia are also usually dark grey due to the Cinereorufa-green content in the alveolate cortex. With the exception of the ecology, the only reliable character distinguishing $C$. furfuracea from $C$. scabrosa is the absence of atranorin.

We have collected samples of a granular to blastidiate lichen in the subalpine belt of the Eastern Carpathians ("Caloplaca scabrosa" in Fig. 3). These saxicolous specimens are very similar to both $C$. furfuracea and $C$. scabrosa. They appear to be closer to $C$. furfuracea in the ITS phylogeny but they share chemistry and ecology with C. scabrosa.

New records. Czech Republic: Northern Moravia: Rýmařov, Karlov, central part of Velký kotel corrie, on phyllitic overhanging rock, $1330-1340 \mathrm{~m}, 2002, Z$. Palice 7024 (PRA); ibid., $50^{\circ} 03^{\prime} 20^{\prime \prime} \mathrm{N}, 17^{\circ} 14^{\prime} \mathrm{E}, 1250$ 1300 m, 2004, f. Vondrák 1907, 1908 \& 1909 (CBFS).

C. "scabrosa". Ukraine: Eastern Carpathians: Svidovets Mts, at glacial lake at bottom of glacial cirque in $\mathrm{N}$ slope, $48^{\circ} 15^{\prime} 41^{\prime \prime} \mathrm{N}, 24^{\circ} 13^{\prime} 22^{\prime \prime} \mathrm{E}$, on sun-exposed baserich sandstone boulders close to water, c. $1300 \mathrm{~m}$, 2007, f. Vondrák 6199 (CBFS).

\section{New species}

\section{Caloplaca emilii Vondrák, Khodos., Cl. Roux \& V. Wirth sp. nov.}

\section{MycoBank No: MB 803332}

Thallus grey or brown-grey, non-pruinose, of more or less flat areoles, with Sedifolia-grey and without anthraquinones. Dark grey blastidia always present at margins of thallus units. Mature apothecia zeorine, usually with brown disc and more or less yellow true exciple, $\mathrm{C} \pm$ purple (with chlorinated anthraquinones). Ascospores broadly ellipsoid, less than $15 \mu \mathrm{m}$ long, with thick septa. Pycnidial tops dark grey. Conidia ellipsoid, not bacilliform.

Type: Bulgaria, Black Sea coast, Kavarna, limestone cliffs on seashore $1.5 \mathrm{~km} \mathrm{NE}$ of Kamen Brjag, $43^{\circ} 27^{\prime} 58 \cdot 76^{\prime \prime} \mathrm{N}, 28^{\circ} 33^{\prime} 55 \cdot 02^{\prime \prime} \mathrm{E}$, on coastal limestone outcrop above supralittoral zone, 6 April 2007, f. Vondrák 6600 (CBFS-holotype; KHER-isotype). ITS sequence of the holotype: KC416101.

Images of the German sample are available on the lichenological web page at the University of South Bohemia http://botanika.bf.jcu.cz/lichenology/index.php?pg=5.

(Figs 1B, 4, 7B)
Thallus forming irregular spots, browngrey or pale to dark grey, to several $\mathrm{cm}$ wide; often starting on other crustose lichens; of tightly arranged, angular to rounded, flat to slightly convex, areoles or squamules, $(0 \cdot 3-)$ $0 \cdot 6-0 \cdot 9-1 \cdot 1(-2 \cdot 6) \mathrm{mm}$ diam. $[70 ; 7 ; 0 \cdot 4]$. Thickness of thallus 100-500 $\mu \mathrm{m}$. Medulla well-developed only in thick thalli, but up to $400 \mu \mathrm{m}$ thick; medullary tissue formed of loose prosoplectenchyma; medullary hyphae c. 2-3 $\mu \mathrm{m}$ wide with walls thickened up to 1 $\mu \mathrm{m}$. Algal layer 50-140 $\mu \mathrm{m}$ thick; algal cells globose, c. 5-20 $\mu \mathrm{m}$ diam. Cortex developed in patches, up to $30 \mu \mathrm{m}$ thick, not gelatinous; sometimes only alveolate cortex present. Epinecral layer often present, up to about 10 $\mu \mathrm{m}$ thick. Cortex cells or alveolate cortex cells spherical, thin-walled, about 4-6 $\mu \mathrm{m}$ diam. Blastidia simple, globose, dark grey, always present, produced at margins of areoles or squamules, rarely also on their upper surface, (20-)53-65-95(-210) $\mu \mathrm{m}$ diam. $[60 ; 6 ; 36]$. Extracellular crystals of calcium salts not observed in any thallus part. Pruina absent. Prothallus indistinct or absent. Thallus frequently affected by brown hyphomycetes resembling species of Intralichen.

Apothecia present in c. 50\% of samples collected; rare in northern populations; $(0.3-)$ $0.5-0 \cdot 7-0.9(-1.4) \mathrm{mm}$ diam. [40; $4 ; 0.2]$; zeorine. Disc in shades of brown (orange in young apothecia); true exciple usually yellow (contrasting with disc); thalline exciple in shades of grey; pruina absent. Hymenium colourless, without distinct gelatinous matrix and without extracellular oil drops, c. 70$110 \mu \mathrm{m}$ high; epihymenium ochre to greenyellow. Hypothecium colourless, rarely with extracellular oil drops, more or less flat, $c$. 100-300 $\mu \mathrm{m}$ high, formed of cells variable in shape; subhypothecial algal layer present (algal cells underlying entire hypothecium). Exciple c. $70-110 \mu \mathrm{m}$ wide, formed of true exciple, c. 30-60 $\mu \mathrm{m}$ wide, and thalline exciple, $c$. $10-70 \mu \mathrm{m}$ wide. Upper part of true exciple of thin-walled spherical cells c. 4$6 \times 3-4 \mu \mathrm{m}$. Lower part of palisade prosoplectenchyma of thin-walled cells $c$. 5$12 \times 1 \cdot 5-2 \cdot 0 \mu \mathrm{m}$. Thalline exciple without cortex or with indistinct alveolate cortex. 
Paraphyses $2 \cdot 0-2 \cdot 5 \mu \mathrm{m}$ wide in lower part, but widening gradually to $(2 \cdot 5-) 3 \cdot 0-3 \cdot 5-$ $4.0(-5.0) \mu \mathrm{m}[30 ; 3 ; 0.5]$ in upper part; rarely branched and anastomosed. Asci clavate, c. 50-70 $\times 15-20 \mu \mathrm{m}$. Ascospores polarilocular, $(8 \cdot 0-) 12 \cdot 0-12 \cdot 5-13 \cdot 5(-15 \cdot 0) \times(5 \cdot 0-) 7 \cdot 0-$ $7 \cdot 5-8 \cdot 0(-9.5) \mu \mathrm{m}[50 ; 5 ; 1.5 \& 0.9]$, septa $(4 \cdot 0-) 5 \cdot 0-5 \cdot 5-6 \cdot 0(-7 \cdot 5) \mu \mathrm{m}[50 ; 5 ; 0 \cdot 9]$. Ascospore length/breadth ratio: (1.0-)1.5$1 \cdot 7-1 \cdot 8(-2 \cdot 2)$ [50;5;0.3]; septum width/ ascospore length ratio: $(0 \cdot 30-) 0 \cdot 40-0 \cdot 45-$ $0 \cdot 47(-0 \cdot 60)[50 ; 5 ; 0 \cdot 1]$. Extracellular crystals of calcium salts absent from all apothecial parts.

Pycnidia not common (observed in only three samples), c. 150-200 $\mu \mathrm{m}$ wide, with several partly separated chambers (Xanthoria-type), distinguished by their darker grey tops on the thallus surface. Conidiophores formed of isodiametric cells, c. 2-4 $\mu \mathrm{m}$ diam. Conidia ellipsoid, broadly ellipsoid or tear-shaped, rather uniform in size, $2 \cdot 0$ $2.5 \times 1.5 \mu \mathrm{m}$.

Chemistry. True exciple, medulla and lower cortex non-amyloid (I-); hymenium and hypothecium amyloid (I+). Uppermost cells in cortical tissue of thallus and thalline exciple contain Sedifolia-grey (grey in water, $\mathrm{K}+$ violet, $\mathrm{N}+$ red, $\mathrm{H}_{2} \mathrm{SO}_{4}+$ red, I+ blue). Content of Sedifolia-grey is higher in pycnidial tops. Epihymenium and outer cells in the true exciple contain anthraquinones: fragilin (major) and 7-Cl-emodin (HPLC done in sample JV6597).

Etymology. The epithet is derived from the name of our great friend Emil Červenka, who supported the first author during difficult times.

Similar taxa. Caloplaca areolata (Zahlbr.) Clauzade (without blastidia), C. chlorina (Flot.) Sandst. and $C$. isidiigera Vězda (with blastidia but with lecanorine apothecia and bacilliform conidia), C. concreticola Vondrák $\&$ Khodos. (with blastidia but without anthraquinones in apothecia), C. soralifera Vondrák \& Hrouzek (with soredia, often pruinose) and C. xerica Poelt \& Vězda (usually with isidia, without flat areoles, with larger ascospores). A little-known blastidiate morphotype of Caloplaca atroflava (Turner) Mong. is a similar lichen; it is very common in Central Europe, but occurs mainly on noncalcareous rocks (orange, C- apothecia, without chlorinated anthraquinones, blastidia usually overgrowing most of thallus surface).

Phylogeny. In the ITS phylogeny (Fig. 4), Caloplaca emilii is definitely placed in the $C$. xerica group (sensu Vondrák et al. 2012b). It forms a well-circumscribed clade $(\mathrm{PP}=1 \cdot 0)$, sister to $C$. areolata. Both taxa form a wellsupported monophyletic group ( $P P=0.99)$.

Ecology and distribution. Caloplaca emilii occurs on sun-exposed, usually horizontal, faces of limestone outcrops in fast-drying places in steppes, forest-steppes or in open Mediterranean shrub vegetation, mainly in the Placocarpetum schaereri (Roux 1978: 120130). Co-occurring lichens are Acarospora cervina, Aspicilia calcarea, A. contorta, Bagliettoa calciseda, Caloplaca aurantia, C. chalybaea, C. coronata, $C$. crenulatella s. lat., $C$. inconnexa, C. lactea, C. teicholyta, C. variabilis, Candelariella aurella, Diplotomma hedinii, D. venustum s. str., Heteroplacidium fusculum, Lecanora muralis s. lat., Lobothallia cheresina s. lat., $L$. radiosa, Placocarpus schaereri, Placopyrenium canellum, Rinodina calcarea, $R$. ocellata, $R$. bischoffi, Verrucaria lecideoides, $V$. macrostoma f. furfuracea, and $V$. nigrescens s. lat.

The species is already known from Germany (as the blastidiate variant of Caloplaca areolata in Wirth et al. 2011). Nevertheless, this lichen has a rather southern distribution in Europe; it is probably most common in the Mediterranean basin and adjacent areas, such as France, Italy, Spain, mainly in the supramediterranean and montane belts (Roux 1978: 124, as C. areolata). Although it is common in continental areas around the Black Sea, we do not know it from continental areas east of the Mediterranean basin. In southern areas, it sometimes grows with its close relative $C$. areolata (for example in southern France and Greece). Both taxa have similar ecology, but $C$. areolata without vegetative diaspores appears to be restricted to the Mediterranean region, whereas the blastidiate $C$. emilii also occurs in isolated localities far to the north (Fig. 1B). The 


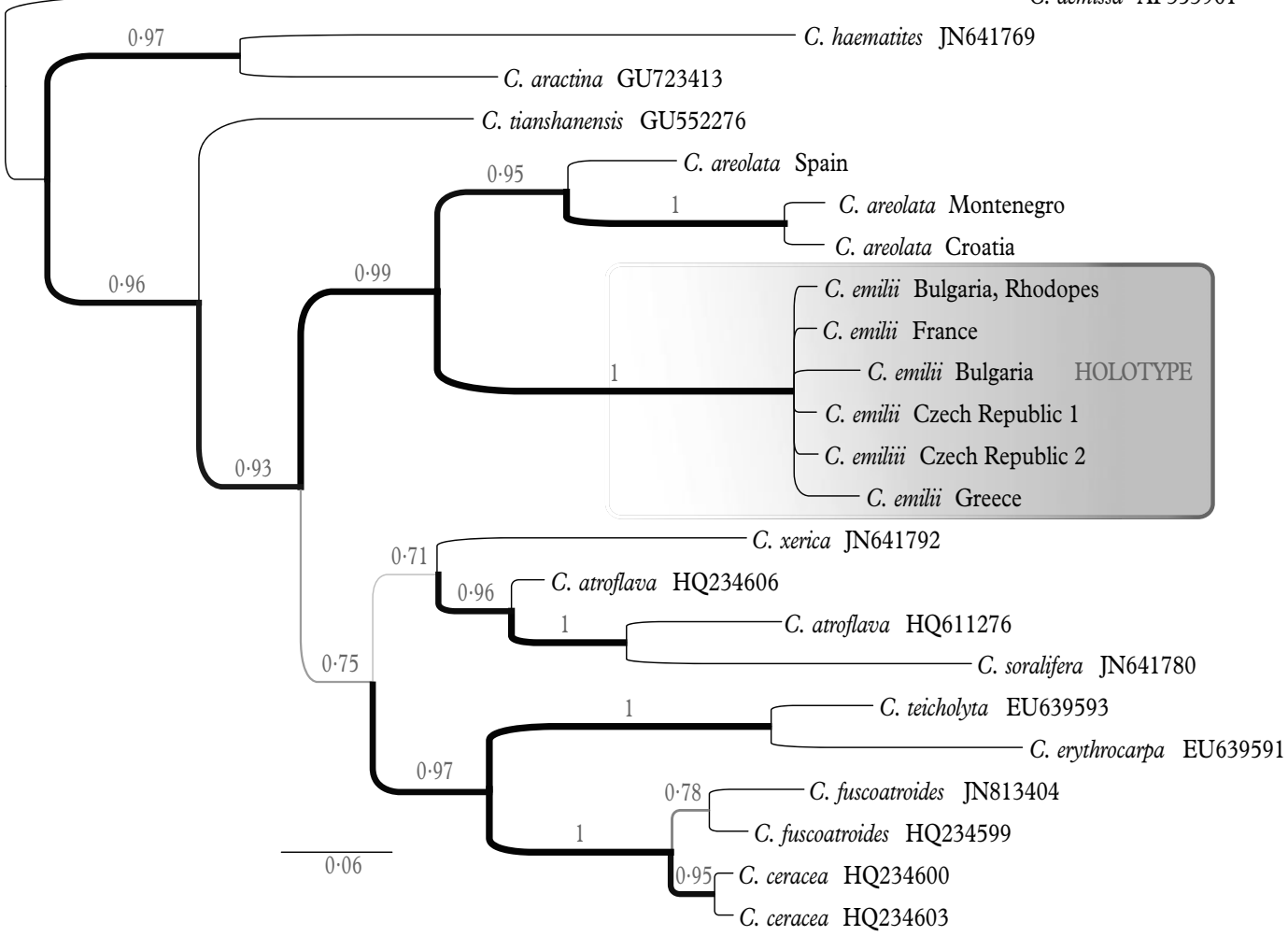

FIG. 4. Bayesian ITS phylogeny of the Caloplaca xerica group including C. emilii (in the grey square) and C. areolata.

ability to reproduce vegetatively may have facilitated the northward extension of its distribution. A similar situation is observed in other Mediterranean lichens from the $C$. xerica group; sorediate/blastidiate $C$. albolutescens (Nyl.) H. Olivier and C. teicholyta (Ach.) J. Steiner are known from much more northern territories than the closely related C. erythrocarpa (Pers.) Zwackh, which is without vegetative diaspores.

Taxonomic notes. Caloplaca emilii is well known from the Mediterranean regions of France, where it has been named $C$. areolata (Clauzade 1963, 1965, 1969; Roux 1978) or later C. isidiigera (Roux 1982, 1984; Boissière et al. 1989; Houmeau \& Roux 1991; Roux \& Gueidan 2002; Bricaud 2007). However, these names belong to other taxa; C. areolata lacks vegetative diaspores (see also under ecology) and C. isidiigera is an unrelated species with lecanorine apothecia and a (sub-)alpine distribution (Vězda 1978; Šoun et al. 2011).

Caloplaca areolata has recently been considered a synonym of $C$. spalatensis Zahlbr. (e.g. Nimis \& Martellos 2008). This synonymization is incorrect, because $C$. spalatensis is a very different lichen which belongs to the $C$. crenularia group (images of both holotypes, deposited in the herbarium W, are available on the lichenological web page at the University of South Bohemia http://botanika.bf.jcu.cz/lichenology/index.php?pg=5).

Paratypes. Austria: Niederösterreich: Wien, Hainburg an der Donau, rocks on SW slopes of hill Braunberg $\mathrm{NE}$ of town, $48^{\circ} 09^{\prime} 10^{\prime \prime} \mathrm{N}, 16^{\circ} 57^{\prime} 12^{\prime \prime} \mathrm{E}, 280 \mathrm{~m}, 2012$, f. Vondrák 9570 (CBFS).-Bulgaria: Black Sea coast: Kavarna, Kamen Brjag, $43^{\circ} 27^{\prime} 59^{\prime \prime} \mathrm{N}, 28^{\circ} 33^{\prime} 55^{\prime \prime} \mathrm{E}$, 2007, F. Vondrák 6600 (CBFS). The Rhodopes: Madzharovo, Silen, Byal Kladenets, in valley below village, 
$41^{\circ} 37^{\prime} \mathrm{N}, 25^{\circ} 40^{\prime} \mathrm{E}, 350 \mathrm{~m}, 2004$, F. Vondrák 2223 (CBFS).-Czech Republic: Southern Moravia: Mikulov, in town, ruin of castle Kozí Hrádek, $48^{\circ} 48^{\prime} 34^{\prime \prime} \mathrm{N}$, $16^{\circ} 38^{\prime} 17^{\prime \prime} \mathrm{E}, 2011$, f. Vondrák 9358 E O. Vondráková (CBFS); Mikulov, Klentnice, SE slope of hill Pálava, $48^{\circ} 51^{\prime} 22^{\prime \prime} \mathrm{N}, 16^{\circ} 38^{\prime} 33^{\prime \prime} \mathrm{E}, 350-400 \mathrm{~m}, 2012$, F. Vondrák 9581 (CBFS); Mikulov, Klentnice, at ruin of Sirotči hrádek, $48^{\circ} 50^{\prime} 43^{\prime \prime} \mathrm{N}, 16^{\circ} 38^{\prime} 25^{\prime \prime} \mathrm{E}, c .410 \mathrm{~m}$, 2011, f. Vondrák 9357 E O. Vondráková (CBFS).France: Provence: Vaucluse, Gordes, entre les Devens et Lancie, sur dalle de molasse miocène au ras su sol, $43.9026^{\circ} \mathrm{N}, 5 \cdot 1931^{\circ} \mathrm{E}, 275 \mathrm{~m}, 1975, G$. Clauzade (MARSSJ 189); Vaucluse, Mirabeau, 520 m, 2005, C. Roux 23475 (hb. Roux).-Germany: Bayern: Oberfranken, Fränkische Alb: Kleinziegenfelder Tal, Grenzstein, 1976, V. Wirth 6101 (STU).-Greece: Attica: Poros, limestone outcrops in N-part of island, $37^{\circ} 31^{\prime} 28^{\prime \prime} \mathrm{N}, 23^{\circ} 29^{\prime} 10^{\prime \prime} \mathrm{E}$, c. $200 \mathrm{~m}, 2010$, F. Vondrák 8726, 8832 E O. Vondráková (CBFS).-Romania: Dobrogea: Târguşor, $44^{\circ} 27^{\prime} 46 \cdot 26^{\prime \prime} \mathrm{N}, 28^{\circ} 28^{\prime} 07 \cdot 59^{\prime \prime} \mathrm{E}$, 2007, f. Vondrák 6599 (CBFS); Tulcea, Enisala, $44^{\circ} 52^{\prime} 42 \cdot 09^{\prime \prime} \mathrm{N}, 28^{\circ} 51^{\prime} 01 \cdot 27^{\prime \prime} \mathrm{E}, 2007$, f. Vondrák 6604 (CBFS); Tulcea, Popina Island, $44^{\circ} 58^{\prime} 03^{\prime \prime} \mathrm{N}$, $28^{\circ} 58^{\prime} 57^{\prime \prime} \mathrm{E}, 2007, \mathcal{F}$. Vondrák 6596, 6597, 6598 \& 7149 (CBFS).-UKraine: Kherson region: Berislav, Burgunka, 2008, A. Khodosovtsev $\mathbb{G}$ G. Naumovich (KHER, dupl. in CBFS).

\section{Caloplaca molariformis Frolov, Vondrák, Nadyeina \& Khodos. sp. nov.}

\section{MycoBank No: MB 803333}

Anthraquinones entirely absent. Thallus epilithic, thick, ochre or dark grey, pruinose in spots, with Sedifolia-grey in superficial fungal cells. Blastidia and/or soralia always present. Thallus formed by high algal and fungal stacks (sensu Vondrák \& Kubásek 2013). Fungal stacks of colourless palisade prosoplectenchyma, of cells elongated vertically. The upper thallus surface with ridges derived from the epinecral layer, above fungal stacks (similar structure is described in South African "Fensterflechten" by Vogel 1955). Epihymenium and outer part of true exciple brown to grey, with Sedifolia-grey, $\mathrm{K}+$ (slightly) violet to violet-brown. Ascospores c. 14-18 $\mu \mathrm{m}$ long with rather thin septa, c. $3 \mu \mathrm{m}$ wide.

Type: Slovakia, Cerová vrchovina upland, Filakovo, Hajnáčka, Surice, SW-slope of the hill Soví hrad, $48^{\circ} 13^{\prime} 34^{\prime \prime} \mathrm{N}, 19^{\circ} 54^{\prime} 45^{\prime \prime} \mathrm{E}$, on lime-rich outcrop of volcanic pyroclastics in sun-exposed abandoned quarry, $c$. 250 m, 8 November 2012, f. Vondrák 10192 (CBFSholotype; isotypes to be distributed in Exsiccates of Caloplaca, fasc. 4). ITS sequence of the holotype: KC416142.

More images available on the lichenological web page at the University of South Bohemia http://botanika.bf. jcu.cz/lichenology/index.php?pg=5.

(Figs 5, 7C; fig. 2 in Vondrák \& Kubásek 2013)
Thallus epilithic, ochre, white-grey to dark grey, usually with white pruinose spots, forming irregular spots to several $\mathrm{cm}$ wide; of tightly arranged, angular to rounded, more or less flat areoles or somewhat umbilicate squamules, $(0 \cdot 44-) 0 \cdot 70-0 \cdot 95-1 \cdot 26$ $(-2 \cdot 05) \mathrm{mm}$ diam. [100; 10; 0.35]. Marginal areoles sometimes bigger than areoles in the centre. Several small, tightly arranged areoles may merge to form larger units, but on the contrary, large areoles are sometimes divided into smaller subareoles due to secondary crevices. Thickness of the thallus, together with brown (probably necrotic) lower medulla $(0 \cdot 2-) 0 \cdot 6-1 \cdot 2-2 \cdot 2(-5 \cdot 0) \mathrm{mm}[30 ; 3$; $1.0]$; thickness of the thallus without lowermost brown part $(0 \cdot 1-) 0 \cdot 3-0 \cdot 4-0 \cdot 5(-0 \cdot 9)$ $\mathrm{mm}[30 ; 3 ; 0 \cdot 2]$. The brown lower medulla usually distinct, up to 12.5 times thicker than the rest of the thallus. Colourless medulla also present, (50-)140-235-330(-550) $\mu \mathrm{m}$ thick [26; $3 ; 145]$; cells hardly observable due to presence of extracellular crystals insoluble in $\mathrm{KOH}$ and only partly dissolved and recrystallized into needles in $\mathrm{H}_{2} \mathrm{SO}_{4}$. Algal cells arranged in vertical stacks, (30-) $67-91-129(-250)$ wide $[47 ; 6 ; 44]$, and (100-)223-263-334(-550) $\mu \mathrm{m}$ high [47; 6; 112]. Algal cells globose, $(8 \cdot 0-) 12 \cdot 6-13 \cdot 7-$ $14 \cdot 5(-22 \cdot 0) \mu \mathrm{m}$ diam. $[30 ; 3 ; 3 \cdot 2]$. Cortex above the algal stacks absent or indistinct, alveolate cortex present, up to $c .15-30 \mu \mathrm{m}$ thick; upper fungal cells in algal stacks grey, containing Sedifolia-grey. Fungal stacks (measured with epinecral layer) (13-)45-86$120(-270)$ wide $[46 ; 6 ; 55]$ and $(75-) 180-$ $322-505(-750) \mu \mathrm{m}$ high $[46 ; 6 ; 165]$; formed by vertically oriented palisade prosoplectenchyma; size of cells in the middle part of stacks (4.5-)9.4-11.9-13.3(-18.0) $\times$ (3.0-)3.7-4.3-4.8(6.5) $\mu \mathrm{m}[30 ; 3 ; 3.9 \&$ $0 \cdot 9]$. In lower part of stacks, cells longer and narrower; in uppermost part, cells almost isodiametric, c. 4-7 $\mu \mathrm{m}$ diam. Epinecral layer above fungal stacks usually well-developed, (5-)20-95-200(-350) $\mu \mathrm{m}$ thick $[81 ; 9 ; 72]$; dead cells (colourless in cotton blue) recognizable in the lower part. Boundary between epinecral layer and upper cells of the fungal stack sometimes indistinct, but recognizable after $\mathrm{KOH}$ treatment as a sordid grey-violet 


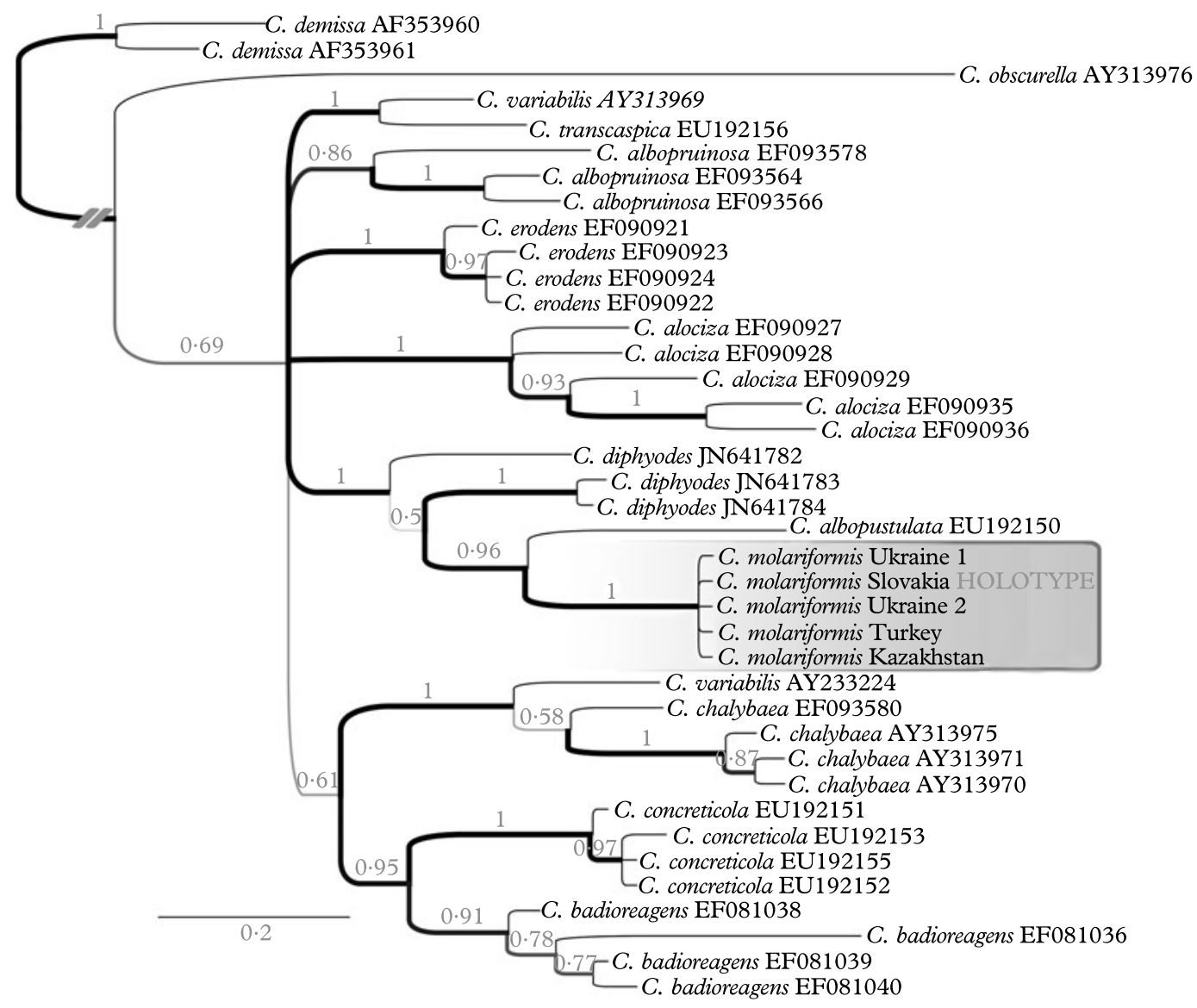

FIG. 5. Bayesian ITS phylogeny of the Pyrenodesmia subgroup of Caloplaca, including C. molariformis clade delimited by the grey square.

line caused by traces of the Sedifolia-grey in uppermost fungal stack cells. Epinecral layer often forms distinct ridges on thallus surface above fungal stacks, because it is absent from surface of algal stacks (Fig. 7C). Epinecral ridges best developed in samples from deserts of Western Kazakhstan, but less distinct in samples from Slovakia and Ukraine. Fungal stacks sometimes reaching medulla at the bottom and the boundary between the stacks and medulla recognized by the crystals abundant in medulla but absent from stacks. Margins of areoles and squamules and the lower surface of squamules usually with cortex, up to $c .20 \mu \mathrm{m}$ thick, of isodiametric cells, c. 4-7 $\mu \mathrm{m}$ diam. Vegetative diaspores are blastidia (always present) or rarely soredia; sometimes diaspores poorly developed, present only on few areoles. Blastidia simple, more or less globose, (30-)54-67-89(-150) $\mu \mathrm{m}$ diam. $[52 ; 6 ; 25]$, dark grey, present on the margin and upper surface of areoles and squamules; detached blastidia occasionally cover the whole surface. Blastidia sometimes with appearance of consoredia, with internal soredia-like structures. Extracellular crystals soluble in $\mathrm{KOH}$ and Sedifolia-grey pigment present in outer fungal cells of blastidia. Soralia rarely observed, on the upper surface between epinecral ridges; soredia c. 25-40 $\mu \mathrm{m}$ diam. White pruina always present, better developed between epinecral ridges. 
Prothallus indistinct or absent. Thallus frequently affected by brown hyphomycetes resembling species of Intralichen.

Apothecia (0.33-)0.42-0.55-0.72(-1.32) $\mathrm{mm}$ diam. $[100 ; 10 ; 0 \cdot 15]$, zeorine or rarely almost lecanorine; mature apothecia sessile, usually not abundant on thallus, sometimes absent. Richly fertile populations known only from Slovakia and Ukraine. Disc brown to black, not pruinose, sometimes cracked; true exciple concolourous with the disc, occasionally white pruinose; thalline exciple concolourous with the thallus, with white pruina. Hymenium (63-)91-102-109(-175) $\mu \mathrm{m}$ high $[30 ; 3 ; 23]$, colourless, often with very small $(<1 \mu \mathrm{m})$ extracellular oil drops, sometimes strongly inspersed with extracellular oil drops up to c. $2 \mu \mathrm{m}$ diam., sometimes not inspersed; without crystals. Epihymenium brown, grey or grey-brown. Hypothecium colourless, underlain by the algal layer, usually with extracellular oil drops, without extracellular crystals; with a central conical extension downward, (75-) 153-174-185 (-275) $\mu \mathrm{m}$ high $[30 ; 3 ; 48]$; formed of thin-walled cells variable in shape. Exciple c. 10-160 $\mu \mathrm{m}$ wide. True exciple (10-) $18-35-54(-93) \mu \mathrm{m}$ wide $[30 ; 3 ; 22]$, and thalline exciple $(0-) 18-24-27(-68) \mu \mathrm{m}$ wide $[30 ; 3 ; 20]$. Upper part of the true exciple grey-brown, brown-grey or grey, of thin-walled cells $(4 \cdot 0-) 6 \cdot 2-6 \cdot 6-7 \cdot 3(-10 \cdot 0) \times$ $(2 \cdot 0-) 3 \cdot 4-4 \cdot 5-5 \cdot 2(-8 \cdot 0) \mu \mathrm{m}[100 ; 10 ; 1 \cdot 1$ $\& 1 \cdot 1]$. Lower part colourless, of palisade prosoplectenchyma of thin-walled cells $(6 \cdot 0-)$ $7 \cdot 7-8 \cdot 2-8 \cdot 7(-11 \cdot 5) \times(2 \cdot 0-) 2 \cdot 4-2 \cdot 8-3 \cdot 3$

$(-5 \cdot 0) \mu \mathrm{m}[30 ; 3 ; 1.3 \& 0 \cdot 8]$. Thalline exciple sometimes with cortex in its upper part, c. 8$20 \mu \mathrm{m}$ thick; cortex changing into alveolate cortex in the lower part of thalline exciple. Cells of the cortex spherical, c. 3.5-7.0 $\mu \mathrm{m}$ diam., often hardly observed due to extracellular crystals insoluble in $\mathrm{KOH}$. Paraphyses $(1 \cdot 5-) 2 \cdot 1-2 \cdot 3-2 \cdot 8(-3 \cdot 5) \mu \mathrm{m}$ wide $[100 ; 10$; $0.4]$ in lower part, but widening gradually to (3.0-)3.5-4.4-5.5(-6.5) $\mu \mathrm{m}[100 ; 10 ; 0 \cdot 8]$ in upper part; rarely branched and anastomosed; the uppermost cell of paraphyses usually dead and deformed. Asci clavate, $(40-) 58-64-69(-85) \times(12-) 17-20-21(-28)$ $\mu \mathrm{m}[30 ; 3 ; 1 \& 10]$. Ascospores polarilocular, $(12 \cdot 0-) 14 \cdot 3-16 \cdot 2-18 \cdot 3(-23 \cdot 0) \times(5 \cdot 0-)$ 6.4-7.7-9.1(10.5) $\mu \mathrm{m}[70 ; 8 ; 2 \cdot 3$ \& $1 \cdot 3]$; septa $(2 \cdot 0-) 2 \cdot 6-3 \cdot 0-3 \cdot 3(-4 \cdot 0) \quad \mu \mathrm{m}$ wide $[70 ; 8 ; 0 \cdot 5]$. Ascospore length/breadth ratio: (1.40-)1.98-2.12-2.27(-2.86) [70; 8; 0.32]; septum width/ascospore length ratio: $(0 \cdot 11-)$ $0 \cdot 17-0 \cdot 19-0 \cdot 22(-0 \cdot 30)$ [70; 8; 0.04]. Ascospores with well-developed septa often absent.

Pycnidia rare, c. 140-190 $\mu \mathrm{m}$ wide, mainly with a single chamber, present on the upper thallus surface, but also on the lower surface of squamules; superficially hardly distinguishable. Old pycnidial chambers sometimes filled by crystals insoluble in $\mathrm{KOH}$. Conidiophores of spherical or triangular, more or less isodiametric cells. Conidia narrowly to broadly ellipsoid, $2.5-4.5 \times 1.5-2.0 \mu \mathrm{m}$ $[14 ; 2 ; 0 \cdot 2 \& 0 \cdot 5]$.

Chemistry. Spot tests: thallus $\mathrm{K} \pm$ violet (sometimes not observable or observable only in spots with blastidia and soredia), apothecia $\mathrm{K}-$, thallus and apothecia $\mathrm{C}-, \mathrm{P}-$, UV-. Epihymenium, uppermost true exciple, uppermost fungal cells in thallus and vegetative diaspores contain Sedifolia-grey (grey or invisible in water, $\mathrm{K}+$ sordid violet). The reaction above fungal stacks usually weaker than above algal stacks. Strongest reaction in superficial hyphae of vegetative diaspores. True exciple non-amyloid (I-); hymenium and hypothecium amyloid (I+). No substances revealed by HPLC (apothecia and thallus of an isotype were investigated).

Etymology. Areoles and squamules of the lichen thallus often resemble molars of herbivores.

Similar taxa. The thallus anatomy, with tissues in stacks, is very rare within the Pyrenodesmia subgroup of Caloplaca. It is present in one known species only, Caloplaca albovariegata (B. de Lesd.) Wetmore, which is very similar to $C$. molariformis but has no vegetative diaspores (Wetmore 1994; lectotype in UPS seen). This species was described from North America, but similar morphotypes are known in continental Eurasia (our observations). Zhou et al. (2012) reported a taxon with tissues in stacks from China and named 
it $C$. albovariegata, but it has a thallus surface without ridges derived from the epinecral layer and it does not resemble $C$. molariformis. Other similar taxa are Caloplaca albopustulata Khodos. \& S.Y. Kondr. (with pustules and schisidia), C. bullata (Müll. Arg.) Zahlbr. (bullate thallus without vegetative diaspores), C. concreticola (with soralia) and C. transcaspica (Nyl.) Zahlbr. (without vegetative diaspores), but all these taxa have thallus tissues arranged in horizontal layers, not in stacks. They also do not have specific ridges derived from the epinecral layer. (Type specimens and other comparative material studied by the authors.)

Phylogeny. In the ITS phylogeny (Fig. 5), Caloplaca molariformis is placed in the $C$. variabilis group, closely related to $C$. albopustulata.

Distribution and ecology. Caloplaca molariformis is mainly distributed in steppes and deserts of Iran, Kazakhstan, continental Turkey and southern Russia, at altitudes of 50$2100 \mathrm{~m}$. Two isolated localities are also known from the steppe or forest-steppe, in eastern Ukraine and southern Slovakia. The species occurs in sunny habitats on soft limestone, chalk, calcareous sandstone or tuffs with evident content of lime (always reacting with $\mathrm{HCl}$ ). Co-occurring lichen taxa include Acarospora spp., Aspicilia spp., Caloplaca concreticola, C. crenulatella s. lat., C. decipiens, C. Alavocitrina, C. soralifera, $C$. sororicida, $C$. teicholyta, C. tominii, C. transcaspica s. lat., C. xerica, Candelariella aurella, Lecanora muralis s. lat., Lemmopsis arnoldiana, Lichinella sp., Verrucariaceae spp. (e.g. Staurothele frustulenta, Verrucaria macrostoma, V. nigrescens agg.).

Paratypes. Iran: West Azerbaijan: Lake Urmia, rocks at road c. $2 \mathrm{~km} \mathrm{~N}$ of Saraydeh, $37^{\circ} 52^{\prime} 59^{\prime \prime} \mathrm{N}$, $45^{\circ} 34^{\prime} 26^{\prime \prime} \mathrm{E}, 1280 \mathrm{~m}, 2007$, f. Vondrák 5556 (CBFS); Khoy, airport, $38^{\circ} 25^{\prime} 16 \cdot 17^{\prime \prime} \mathrm{N}, 44^{\circ} 54^{\prime} 24 \cdot 05^{\prime \prime} \mathrm{E}, 1180$ $\mathrm{m}, 2007, \mathcal{F}$. Vondrák 5801 (CBFS); Lake Urmia, rocky outcrops near coast $\mathrm{N}$ of Aq Gonbad, $37^{\circ} 49^{\prime} 12 \cdot 02^{\prime \prime} \mathrm{N}$, $45^{\circ} 25^{\prime} 09.61^{\prime \prime} \mathrm{E}$, c. $1290 \mathrm{~m}, 2007$, F. Vondrák 5846 (CBFS).-Kazakhstan: Mangistau province: Mangistau district, village Shetpe, West Karatau ridge, c. $15 \mathrm{~km} \mathrm{~N}$ of village, $44^{\circ} 14^{\prime} 35^{\prime \prime} \mathrm{N}, 52^{\circ} 03^{\prime} 19^{\prime \prime} \mathrm{E}, 100 \mathrm{~m}, 2009, A$. Khodosovtsev 7775-7781 Eீ F. Vondrák 8262, 8247, 9477 \& 9487 (CBFS, KHER); Beyneu district, village
Beyneu, c. $50 \mathrm{~km} \mathrm{SW}$ of town at road to Aktau, valley of salt river Manashi, $45^{\circ} 01^{\prime} 26^{\prime \prime} \mathrm{N}, 54^{\circ} 59^{\prime} 56^{\prime \prime} \mathrm{E}, 50 \mathrm{~m}$, 2009, A. Khodosovtsev E f. Vondrák 9483 (CBFS); Mangistau district, West Aktau ridge, soft valley with rocky outcrops at river Akespe, $44^{\circ} 24^{\prime} 21^{\prime \prime} \mathrm{N}, 51^{\circ} 35^{\prime} 59^{\prime \prime} \mathrm{E}$, $100 \mathrm{~m}, 2009$, A. Khodosovtsev Eீ F. Vondrák 9486 (CBFS); Mangistau district, at road between village Shetpe and Say-Utes, c. $30 \mathrm{~km} \mathrm{SW}$ of Say-Utes, $44^{\circ} 09^{\prime} 20^{\prime \prime} \mathrm{N}, 52^{\circ} 39^{\prime} 10^{\prime \prime} \mathrm{E}, 260 \mathrm{~m}, 2009, A$. Khodosovtsev E F. Vondrák 9506 (CBFS); Mangistau district, East Karatau ridge, rocks at road between Zhatybay and Shetpe, c. $30 \mathrm{~km} \mathrm{SW}$ of Shetpe, $43^{\circ} 57^{\prime} 00^{\prime \prime} \mathrm{N}$, $52^{\circ} 05^{\prime} 52^{\prime \prime} \mathrm{E}, 180 \mathrm{~m}, 2009, A$. Khodosovtsev $\mathcal{E} \mathcal{F}$. Vondrák 9499 (CBFS)._Russia: Orenburgskaya Oblast': Orenburg, village Mikhaylovka (c. $30 \mathrm{~km}$ SES of city), Khanskaya gora hill, $\mathrm{S}$ of village, above brook Berd'yanka, $51^{\circ} 25^{\prime} 48^{\prime \prime} \mathrm{N}, 55^{\circ} 26^{\prime} 27^{\prime \prime} \mathrm{E}$, c. $200 \mathrm{~m}, 2011$, I. Frolov $\mathcal{E}$ f. Vondrák 9456 (CBFS); Saraktash district, protected area Kamennaya, rock outcrops in S-slope above river Sakmara, $51^{\circ} 56^{\prime} 53^{\prime \prime} \mathrm{N}, 55^{\circ} 58^{\prime} 23^{\prime \prime} \mathrm{E}, 180 \mathrm{~m}$, 2012, I. Frolov Eீ F. Vondrák 10225 (CBFS). Republic of Altay: Kosh-Agach district, Kosh-Agach, TelengitSortogoy, S-slopes of Kuray Ridge (easternmost part), c. $6 \mathrm{~km} \mathrm{~N}$ of village, $50^{\circ} 04^{\prime} 24^{\prime \prime} \mathrm{N}, 88^{\circ} 42^{\prime} 30^{\prime \prime} \mathrm{E}, 2000-$ $2100 \mathrm{~m}, 2012$, I. Frolov E f. Vondrák 10224 (CBFS).-Slovakia: Cerová vrchovina upland: Filakovo, Hajnáčka, Surice, SW-foot of hill Soví hrad, $48^{\circ} 13^{\prime} 34^{\prime \prime} \mathrm{N}, 19^{\circ} 54^{\prime} 45^{\prime \prime} \mathrm{E}, 240-250 \mathrm{~m}, 2012$, Z. Fakovcová, A. Guttová, f. Liška, Z. Palice 15905 Ej F. Vondrák 10190 (CBFS, PRA; topotypes).-Turkey: Eastern Anatolia: Iğdır, shale hills SE of town, $39^{\circ} 51^{\prime} 23^{\prime \prime} \mathrm{N}$, $44^{\circ} 05^{\prime} 42^{\prime \prime} \mathrm{E}, 1060 \mathrm{~m}, 2007$, F. Vondrák 6463 (CBFS). Central Anatolia: Yozgat, Boğazlıyan, Özler village, $39^{\circ} 04^{\prime} 10^{\prime \prime} \mathrm{N}, 35^{\circ} 08^{\prime} 17^{\prime \prime} \mathrm{E}, 1100 \mathrm{~m}, 2012, \mathcal{F}$. Vondrák 9751 (CBFS); Kayseri, Talas, Derevenk valley, $38^{\circ} 41^{\prime} 23^{\prime \prime} \mathrm{N}, 35^{\circ} 34^{\prime} 52^{\prime \prime} \mathrm{E}, 1230 \mathrm{~m}, 2012$, f. Vondrák $9760,9809 \& 9787$ (CBFS); Kayseri, south-east of Himmetdede, north-west of Kalkanc1k village, montane steppe with shrubs, $38^{\circ} 53^{\prime} 43^{\prime \prime} \mathrm{N}, 35^{\circ} 07^{\prime} 01^{\prime \prime} \mathrm{E}, 1170 \mathrm{~m}$, 2012, F. Vondrák 9791 (CBFS).-UUkraine: Donetsk Upland: Luhansk region, Lutugyno district, steppe slopes with marl outcrops near village Rozkishne, in botanical reserve "Balka Ploska", c. $150 \mathrm{~m}, 2007, O$. Nadyeina 131, 132 \& 134 (KW). [Specimens from Ukraine were published as Caloplaca concreticola in Nadyeina (2009)].

\section{Caloplaca substerilis Vondrák, Palice \& van den Boom sp. nov.}

\section{MycoBank No: MB 803334}

Similar to Caloplaca ulcerosa, but differs in thallus morphology. Thallus endophloeodal, but also forming minute areoles or squamules; sorediate; without any pigments or TLC identifiable compounds. Apothecia up to $c .0 \cdot 5$ $\mathrm{mm}$ diam., orange-red, not pruinose, without chlorinated anthraquinones, biatorine to zeorine. Ascospores broadly ellipsoid, $c$. 10-15 $\mu \mathrm{m}$ long, with septa $c$. 4-6 $\mu \mathrm{m}$ wide. Pycnidia with yellow caps containing anthraquinones. Conidia bacilliform, c. 3-4 × 1.0-1.5 $\mu \mathrm{m}$. 


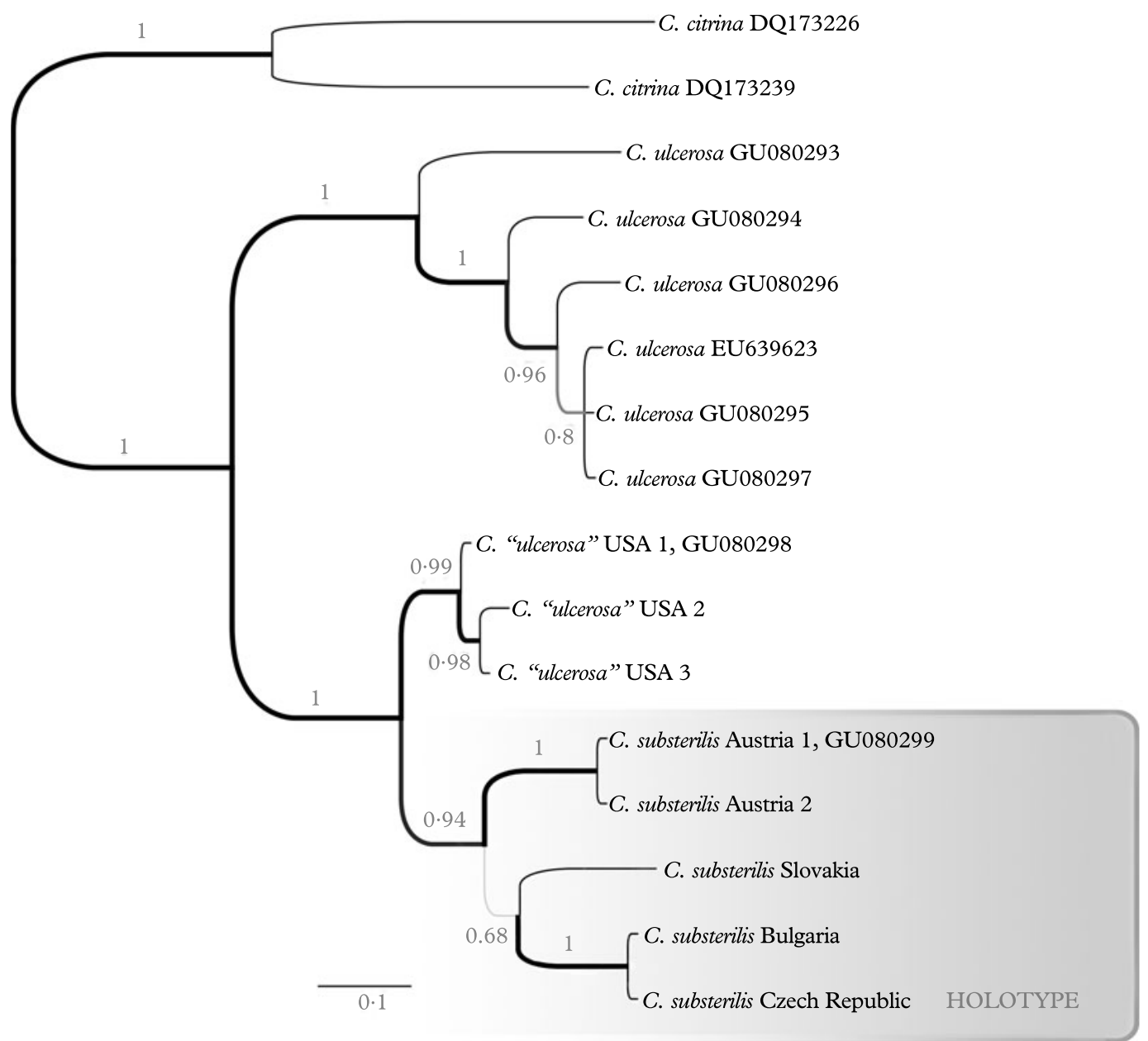

FIG. 6. Bayesian ITS phylogeny of Caloplaca ulcerosa and related taxa including C. substerilis (delimited by the grey square).

Type: Czech Republic, Southern Bohemia, Novohradské hory Mts, Benešov nad Černou, Žofín, alt. 745 $\mathrm{m}, 48^{\circ} 40^{\prime} 29^{\prime \prime} \mathrm{N}, 14^{\circ} 41^{\prime} 38^{\prime \prime} \mathrm{E}$, on bark of solitary Ulmus glabra, 26 May 2010, f. Vondrák 7920, A. Vondráková $\mathcal{E} O$. Redchenko (CBFS-holotype). ITS sequence of the holotype: KC416109.

More images available on the lichenological web page at the University of South Bohemia http://botanika.bf. jcu.cz/lichenology/index.php?pg=5.

(Figs 6, 7D)

Thallus endophloeodal or partly of diffuse tiny squamules (somewhat epiphloedal areolate thallus present in samples from the Alps); sorediate; forming irregular pale grey to white spots or extensive crusts, covering large areas of trunks. Squamules 100-150 $\mu \mathrm{m}$ thick and $(0 \cdot 10-) 0 \cdot 17-0 \cdot 18-0 \cdot 19(-0 \cdot 30) \mathrm{mm}$ diam. [30; $3 ; 0.05]$. Soralia small, usually extended in one direction (rarely rounded), usually up to $0.2 \mathrm{~mm}$ in length, formed in tiny cracks in the tree bark or on margins and lower surface of squamules, usually not in concave, crater-like depressions (typical for Caloplaca ulcerosa Coppins \& P. James); soralia in older lichens often tightly arranged and may resemble a continuous sorediate crust. Soredia without pigmentation, (15-) 23-24-26(-30) $\mu \mathrm{m}$ diam. [40; 4; 4]; consoredia (30-)37-41-46(-65) $\mu \mathrm{m}$ diam. [40; 4; 8]. Fungal cells in soredia or consoredia 


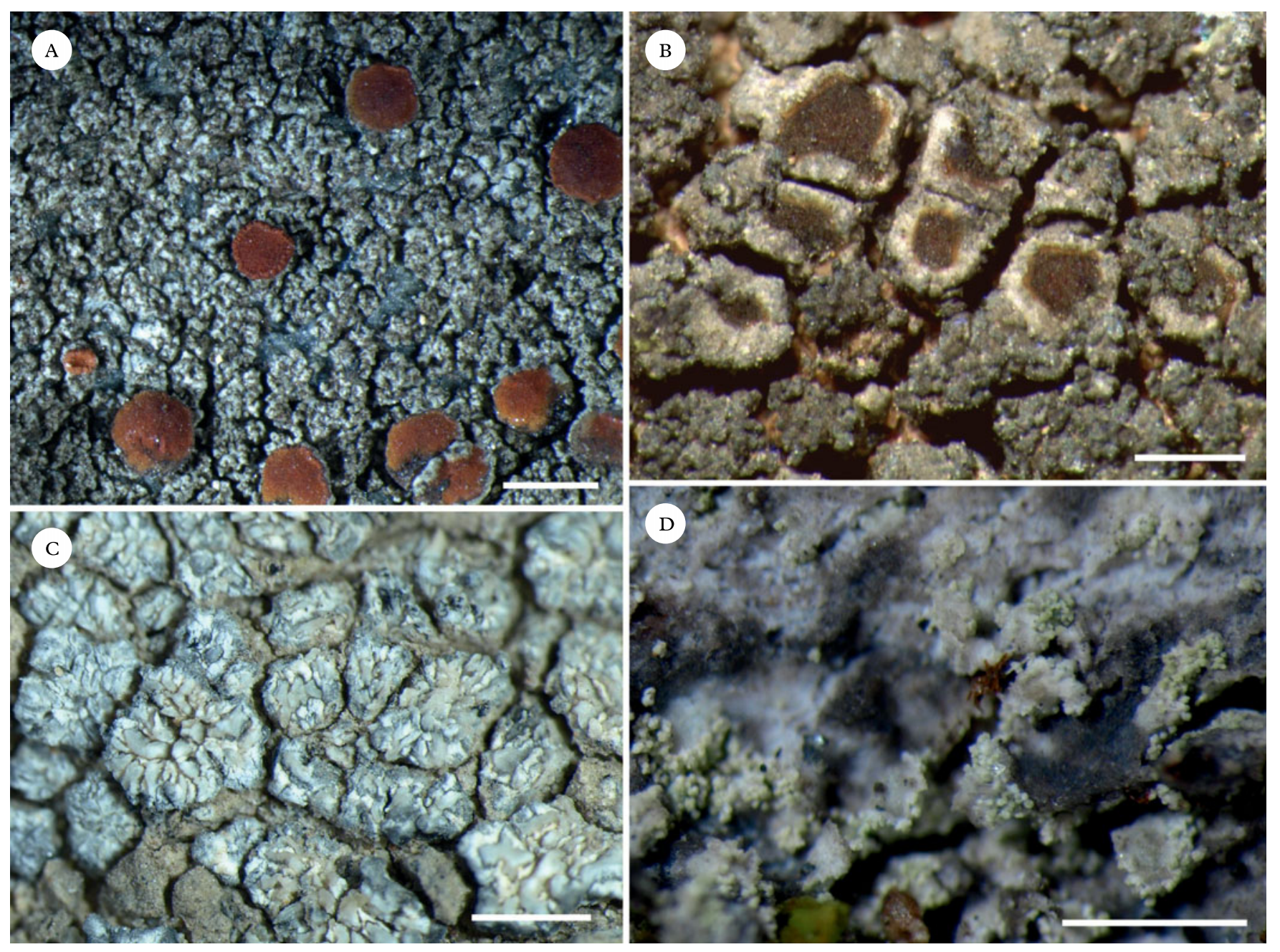


$(3 \cdot 5-) 5 \cdot 4-5 \cdot 5-5 \cdot 7(-7 \cdot 5) \times(2 \cdot 0-) 3 \cdot 2-3 \cdot 3-$ $3 \cdot 4(-4 \cdot 5)[20 ; 2 ; 1 \cdot 1 \& 0 \cdot 8]$. Surface of soredia papillate; papillae formed of fungal cell outgrowths, up to $7 \mu \mathrm{m}$ high. Medulla indistinct or absent. Algal layer forms majority of thallus, c. 100-140 $\mu \mathrm{m}$ thick; algal cells globose, c. 5-20 $\mu \mathrm{m}$ diam.; old cells often internally divided into several irregularly spherical autospores (cell division typical for Trebouxia; e.g. Peksa \& Škaloud 2008). True cortex absent; alveolate cortex developed in patches, up to $20 \mu \mathrm{m}$ thick, of thin-walled, more or less spherical cells. Epinecral layer indistinct. Thallus surface papillate; papillae of the same size and character as those in soredia. Extracellular crystals of calcium salts not observed in any thallus part. Pruina absent. Prothallus indistinct or absent.

Apothecia present in c. $20 \%$ of samples collected (indicated by asterisk in the list of paratypes), but fertile specimens usually with scattered apothecia. The sample from the Alps (van den Boom 15927) with many apothecia is exceptional. Apothecia mostly up to $0.5 \mathrm{~mm}$ diam.; biatorine or zeorine. Disc orange to orange-red; true exciple yelloworange to orange (usually somewhat paler than disc); thalline exciple (when visible) yellow to white; pruina absent or indistinct. Hymenium colourless, somewhat gelatinous, without extracellular oil drops, c. $60-70 \mu \mathrm{m}$ high; epihymenium ochre. Hypothecium colourless, up to $100 \mu \mathrm{m}$ high, more or less flat, but with downward extension through the subhypothecial algal layer in the centre, of thin-walled cells variable in shape; extracellular oil drops not seen. Exciple c. 40-80 $\mu \mathrm{m}$ wide, formed of true exciple, c. 30-70 $\mu \mathrm{m}$ wide, and thalline exciple, $c$. $0-30 \mu \mathrm{m}$ wide. Upper part of true exciple of cells c. 4$8 \times 3-5 \mu \mathrm{m}$, with thin or more than $1 \mu \mathrm{m}$ thick, glutinized walls. Lower part of palisade prosoplectenchyma of thin-walled cells, 6$11 \times 2-4 \mu \mathrm{m}$. Thalline exciple sometimes with alveolate cortex in lower part, up to 30 $\mu \mathrm{m}$ thick, of spherical cells; thalline exciple sometimes sorediate. Paraphyses 1.5-2.0 $\mu \mathrm{m}$ wide in lower part, but about three upper cells widened; branching and anastomosing not observed; paraphyses tips (3.5-) 4.6-4.6$4 \cdot 6(-5 \cdot 5) \mu \mathrm{m}[20 ; 2 ; 0.7]$ wide. Asci clavate, c. 50-60 × 10-16 $\mu \mathrm{m}$. Ascospores polarilocular, $(10 \cdot 0-) 12 \cdot 0-12 \cdot 0-12 \cdot 5(-16 \cdot 5) \times(5 \cdot 0-)$ $7 \cdot 5-8 \cdot 0-8 \cdot 0(-10 \cdot 5) \mu \mathrm{m}[20 ; 2 ; 1.4 \& 1 \cdot 3]$, septa $(4 \cdot 0-) 4 \cdot 5-5 \cdot 0-5 \cdot 5(-8 \cdot 5) \quad \mu \mathrm{m}$ wide $[20 ; 2 ; 1 \cdot 3]$. Ascospore length/breadth ratio: $(1 \cdot 2-) 1 \cdot 6-1 \cdot 6-1 \cdot 7(-2 \cdot 2)[20 ; 2 ; 0 \cdot 3]$; septum width/ascospore length ratio: $(0 \cdot 26-)$ $0 \cdot 34-0 \cdot 40-0 \cdot 42(-0.52)[20 ; 2 ; 0 \cdot 1]$. Extracellular crystals of calcium salts absent from all apothecial parts.

Pycnidia more common than apothecia (observed in c. $50 \%$ of samples), c. 50-100 $\mu \mathrm{m}$ wide, with several partly separated chambers (Xanthoria-type), distinguished by their yellow tops containing anthraquinones. Conidiophores various in height, formed of rectangular, triangular or spherical cells, c. 3$5 \times 4-8 \mu \mathrm{m}$. Conidia usually bacilliform, straight or slightly curved, rarely ellipsoid or tear-shaped, $(2 \cdot 5-) 3 \cdot 2-3 \cdot 4-3 \cdot 5(-5 \cdot 0) \times$ (1.0-) $1 \cdot 2-1 \cdot 2-1 \cdot 3(-1 \cdot 5) \mu \mathrm{m}[20 ; 2 ; 0.7 \&$ $0 \cdot 2]$.

Chemistry. Spot tests: thallus $\mathrm{K}-, \mathrm{C}-, \mathrm{P}-$, $\mathrm{UV} \pm$ white; apothecia $\mathrm{K}+$ purple, $\mathrm{C}-, \mathrm{UV}-$. True exciple non-amyloid (I-). Hymenium and the upper part of hypothecium (subhymenium) amyloid (I+). The $\mathrm{C}$ - reaction of epihymenium and outer cells in the true exciple suggests an absence of chlorinated anthraquinones. No compounds revealed from thallus by TLC.

Etymology. 'Substerilis' reflects the usually sterile occurrence.

Similar taxa. Apothecial characters in the new species are identical to those of the closely related Caloplaca ulcerosa, but they differ in thallus characters. In C. substerilis, the thallus is endophloeodal or of diffuse minute squamules, with marginal soralia, while Caloplaca ulcerosa forms an epiphloedal nonsquamulose thallus with round to irregular soralia formed in crater-like depressions. The latter species further differs in its shorter, ellipsoid conidia (c. 2.5-3.0 $\times 1.5$ $\mu \mathrm{m})$, much higher fertility and in ecology; it is a maritime species (Vondrák et al. 2009b).

White morphotypes of $C$. phlogina (Ach.) Flagey are similar (see Kondratyuk et al. 1998; Vondrák et al. 2010b); they also have 
papillate soredia of similar size without pigmentation, yellow pycnidial caps and an endophloedal thallus, sometimes with minute white squamules. However, C. phlogina differs in frequently having apothecia: these are large (mostly $>0.5 \mathrm{~mm}$ diameter), yelloworange, with a rough surface caused by yellow anthraquinone pruina. Ascospores are significantly smaller with thinner septa: ascospores $(8 \cdot 5-) 10 \cdot 5-10 \cdot 8-11 \cdot 2(-13 \cdot 0) \times$ $(4 \cdot 0-) 5 \cdot 0-5 \cdot 4-5 \cdot 7(-7 \cdot 0) \mu \mathrm{m}[30 ; 3 ; 1 \cdot 0$ \& $0 \cdot 7]$, and septa $(2 \cdot 5-) 3 \cdot 1-3 \cdot 6-3 \cdot 8(-4 \cdot 5) \mu \mathrm{m}$ wide $[30 ; 3 ; 0.6]$.

Sterile thalli may resemble a number of taxa, including: Caloplaca obscurella (J. Lahm) Th. Fr. (with rounded crater-like soralia, brown apothecia), C. sterilis Šoun et al. (on steppe shrubs, with lecanorine apothecia), C. subalpina Vondrák et al. (saxicolous, with lecanorine apothecia and Sedifolia-grey in soredia), Candelariella subdeflexa (Nyl.) Lettau (with different apothecia and more conspicuous squamules producing conidia from the underside) and Rinodina degeliana Coppins (areolate-squamulose thallus with marginal soralia; presence of atranorin and zeorin).

Phylogeny. In the ITS phylogeny (Fig. 6), Caloplaca substerilis forms a well-supported clade, sister to the clade of North American C. "ulcerosa". Both taxa are sister to the European $C$. ulcerosa. Close relatives of these three taxa are not known.

Ecology and distribution. Caloplaca substerilis occurs on nutrient-rich bark of Acer campestris, A. platanoides, Carpinus, Fuglans, Quercus, Populus and Ulmus in well-lit conditions, sometimes overgrowing mosses on bark. Specimens from the Alps were collected on the bark of Sambucus and on Picea abies twigs. Co-occurring lichens are more or less nitrophilous Caloplaca cerinelloides, C. monacensis, C. obscurella, Lecanora hagenii, Macentina dictyospora, Phaeophyscia nigricans, $P$. orbicularis, Physcia spp., Physconia sp., Piccolia ochrophora, Rinodina pityrea, Xanthomendoza fulva and Xanthoria parietina.

Caloplaca substerilis shows continental bias in Europe. It appears to be quite common in the Southern Ural Mountains (most of known localities). It is probably distributed throughout eastern and central Europe in suitable woodland areas with preserved undisturbed solitary elm and poplar trees. So far it is known from Austria, Bulgaria, the Czech Republic, Russia and Slovakia.

Taxonomic notes. The North American taxon called Caloplaca ulcerosa (Wetmore 2004 ) is morphologically more similar to $C$. substerilis than to $C$. ulcerosa $\mathrm{s}$. str. We have examined three samples of the North American taxon (GZU: Iowa, Teloschistaceae Exsiccati 95; Iowa, Wetmore 93230; South Dakota, Advaita 6490), and did not find any diagnostic difference from $C$. substerilis. It corresponds well with the ITS phylogeny, where both taxa form a monophyletic group. The distribution of the North American taxon (Wetmore 2009) and the distribution of $C$. substerilis are similarly continental and different from the maritime distribution pattern of C. ulcerosa s. str. (Vondrák et al. 2009b). Provisionally, we call the North American specimens $C$. "ulcerosa" in Fig. 6.

Two ITS sequences of $C$. substerilis from the Alps form a separate lineage from the other $C$. substerilis sequences. The specimens from the Alps also differ slightly in morphology (frequent apothecia, more or less epiphloeodal thallus and absence of minute squamules) and ecology. While most samples were collected from solitary elms, poplars and oak, specimens from the Alps came from Sambucus bark and spruce twigs. This suggests that the populations from the Alps might represent a distinct infraspecific taxon.

Paratypes (fertile specimens indicated by asterisk). Austria: Steiermark: Schladming, Ramsau am Dachstein, in gorge with road from Ramsau to Weissenbach, c. $850 \mathrm{~m}$, 2009, F. Vondrák 7257 (CBFS). *Kärnten: Gailtaler Alpen, $10 \mathrm{~km}$ WNW of Weissbriach, $0.5 \mathrm{~km}$ SE of Felstritz, open pine forest, $550 \mathrm{~m}, 1994, P$. van den Boom 15927 (hb. van den Boom).-Bulgaria: The Rhodopes: Madzharovo district, Silen, Rabovo, valley of small brook $\mathrm{N}$ of village, $41^{\circ} 37^{\prime} \mathrm{N}, 25^{\circ} 40^{\prime} \mathrm{E}, 250 \mathrm{~m}, 2004$, 7. Vondrák (CBFS, in sample "Caloplaca virescens, Exs. of Caloplaca, Nr 11").-Czech Republic: Southern Bohemia: Novohradské hory Mts, Benešov nad Černou, Žofín, $48^{\circ} 40^{\prime} 29^{\prime \prime} \mathrm{N}, 14^{\circ} 41^{\prime} 38^{\prime \prime} \mathrm{E}, 745 \mathrm{~m}, 2009,2010, Z$. Palice 12943 \& 13676 (PRA, topotypes); Šumava Mts, Borová Lada, Knížecí Pláně, avenue of old trees along 
yellow-marked tourist footpath near abandoned cemetery, $48^{\circ} 57 \cdot 61^{\prime} \mathrm{N}, 013^{\circ} 37 \cdot 19^{\prime} \mathrm{E}, 1000-1020 \mathrm{~m}, 2005$, Z. Palice 8928 (PRA); distr. Jindřichův Hradec, Novobystřická vrchovina, W slope of crest Homolka-Fabián"Lesovna v Dubovici", $49^{\circ} 02^{\prime} \mathrm{N}, 14^{\circ} 58^{\prime} 50^{\prime \prime} \mathrm{E}, 540 \mathrm{~m}$, 2002, M. Kukwa E Z. Palice 6844 (PRA). Western Bohemia: Sumava Mts, Zhưří, valley of Pěnivý potok brook, nearby the settlement Bílý Potok, $49^{\circ} 06 \cdot 3^{\prime} \mathrm{N}$, $13^{\circ} 34 \cdot 1^{\prime} \mathrm{E}, 770 \mathrm{~m}, 2005$, Z. Palice 9414 E F. Palicová (PRA). Southern Moravia: Mikulov, Klentnice, protected area Soutěska, $48^{\circ} 51^{\prime} 48^{\prime \prime} \mathrm{N}, 16^{\circ} 38^{\prime} 40^{\prime \prime} \mathrm{E}, 400 \mathrm{~m}$, 2013, f. Vondrák 10668, 10669, I. Frolov E N. Pirogov (CBFS).--Russia: Chelyabinskaya Oblast': Southern Ural Mts, Ust'-Katav, vill. Orlovka (c. $10 \mathrm{~km} \mathrm{SW}$ of Ust'-Katav), fragments of forest with Ulmus laevis-Ulmus glabra in valley of small brook c. $2 \mathrm{~km} \mathrm{SE}$ of village, $54^{\circ} 52^{\prime} 04^{\prime \prime} \mathrm{N}, 58^{\circ} 06^{\prime} 36^{\prime \prime} \mathrm{E}, 500 \mathrm{~m}, 2012$, f. Vondrák 9963 (CBFS). Orenburgskaya Oblast': Kuvandik, vill. Maloe Churaevo (25 km N of Kuvandik), camp c. $2 \mathrm{~km}$ W of village, steppes and Quercus robur-Tilia cordataUlmus laevis woodland areas around camp, $51^{\circ} 40^{\prime} 9^{\prime \prime} \mathrm{N}$, $57^{\circ} 27^{\prime} 14^{\prime \prime} \mathrm{E}, 250-500 \mathrm{~m}, 2011$, F. Vondrák 9957, 9968 \& 9970 (CBFS); *Saraktash, vill. Andreevka (c. $25 \mathrm{~km}$ NE of Saraktash), alluvial forest with Tilia cordata, Populus sp. and Ulmus laevis, c. $8 \mathrm{~km} \mathrm{NW}$ of village, in valley of river Bolshoy $\mathrm{Ik}, 52^{\circ} 00^{\prime} 29^{\prime \prime} \mathrm{N}, 56^{\circ} 33^{\prime} 39^{\prime \prime} \mathrm{E}$, 150 m, 2012, F. Vondrák 9967 (CBFS). *Republic of Bashkortostan: Irendik range, Sibay, vill. Gabelsha (c. 15 $\mathrm{km} \mathrm{W}$ of Sibay), waterfall Gadelsha in upper stream of brook Khudolaz, $52^{\circ} 45^{\prime} 26^{\prime \prime} \mathrm{N}, 58^{\circ} 22^{\prime} 34^{\prime \prime} \mathrm{E}, 500-800$ $\mathrm{m}, 2011$, F. Vondrák 9361 (CBFS)._Slovakia: West Carpathians: Muránská planina Mts, Mt Cigánka, welllit oak forest on limestone on $\mathrm{S}$ slope, $48^{\circ} 45^{\prime} 18^{\prime \prime} \mathrm{N}$, $20^{\circ} 03^{\prime} 22^{\prime \prime} \mathrm{E}, 800 \mathrm{~m}, 2010, \mathcal{F}$. Halda $\mathcal{E}$ Z. Palice 13441 (PRA).

Linda in Arcadia kindly revised the English and proposed the Latin name molariformis. David Svoboda provided some translations from French. Our research was supported by the program NAKI of the Ministry of Culture of the Czech Republic (DF12P01OVV025), by long-term research development project no. RVO 67985939, by the Centre for Algal Biotechnology Třeboň - ALGATECH (CZ. 1.05/21.00/03.0110), by the institutional resources of the Ministry of Education, Youth and Sports of the Czech Republic and by TÜBİTAK (111T927 coded project).

\section{REFERENCES}

Adachi, J. \& Hasegawa, M. (1996) MOLPHY version 2.3: programs for molecular phylogenetics based on maximum likelihood. Computer Science Monographs 28: 1-150.

Arup, U. \& Åkelius, E. (2009) A taxonomic revision of Caloplaca herbidella and C. furfuracea. Lichenologist 41: 465-480.

Arup, U., Søchting, U. \& Fröden, P. (2013) A new taxonomy of the family Teloschistaceae. Nordic Fournal of Botany 31: 16-83.
Boissière, J.-C., Déruelle, S. \& Roux, C. (1989) Liste provisoire des lichens récoltés dans la région de Chamonix (excursion A.F.L., 1988). Bulletin d'Informations de l'Association Française de Lichénologie 14: 5-18.

Bricaud, O. (2007) Aperçu de la végétation lichénique de quelques stations du Parc naturel régional du Luberon (Vaucluse). Bulletin d'Informations de l'Association Française de Lichénologie 32: 33-86.

Capella-Gutierrez, S., Silla-Martinez, J. M. \& Gabaldon, T. (2009) TrimAl: a tool for automated alignment trimming in large-scale phylogenetic analyses. Bioinformatics 25: 1972-1973.

Clauzade, G. (1963) Quelques lichens intéressants pour la flore française méridionale. Bulletin de la Société linnéenne de Provence 23: 35-44.

Clauzade, G. (1965) Quelques lichens intéressants pour la flore française méridionale. II. Bulletin du Musée d'Histoire Naturelle de Marseille 25: 41-47.

Clauzade, G. (1969) Quelques lichens intéressants pour la flore française méridionale. III. Bulletin du Musée d'Histoire Naturelle de Marseille 29: 101-115.

Ekman, S. (2001) Molecular phylogeny of the Bacidiaceae (Lecanorales, lichenized Ascomycota). Mycological Research 105: 783-797.

Feige, G. B., Lumbsch, H. T., Huneck, S. \& Elix, J. A. (1993) Identification of lichen substances by a standardized high-performance liquid chromatographic method. Fournal of Chromatography A 646: 417-427.

Feuerer, T. (2011) Biodiversity of lichens and lichenicolous fungi. Version 1 August 2011. http://www.checklists. de, Accessed 4 February 2013.

Gardes, M. \& Bruns, T. D. (1993) ITS primers with enhanced specificity for basidiomycetes. Application to the identification of mycorrhizae and rusts. Molecular Ecology 2: 113-118.

Hall, T. A. (1999) BioEdit: a user-friendly biological sequence alignment editor and analysis program for Windows 95/98/NT. Nucleic Acids Symposium Series 41: 95-98.

Houmeau, J.-M. \& Roux, C. (1991) Contribution à l'étude des lichens et des champignons lichénicoles des Pyrénées. Bulletin de la Société Botanique de Centre-Ouest, Nouvelle Série 22: 545-556.

Huelsenbeck, J. P. \& Ronquist, F. (2001) MRBAYES: Bayesian inference of phylogeny. Bioinformatics 17: 754-755.

Katoh, K. \& Toh, H. (2008) Recent developments in the MAFFT multiple sequence alignment program. Briefings in Bioinformatics 9: 286-298.

Keller, I., Bensasson, D. \& Nichols, R. (2007) Transition-transversion bias is not universal: a counter example from grasshopper pseudogenes. PLoS Genetics 3: 222 .

Kondratyuk, S. Y., Søchting, U., Khodosovtsev, O. Y. \& Kärnefelt, I. (1998) Caloplaca scythica, a new species from southern Ukraine. Graphis Scripta 9: 15-19. 
Meyer, B. \& Printzen, C. (2000) Proposal for a standardized nomenclature and characterization of insoluble lichen pigments. Lichenologist 32: 571-583.

Nadyeina, O. (2009) The lichen-forming and lichenicolous fungi of the Donetsk Upland (Ukraine). Mycologia Balcanica 6: 37-53.

Navarro-Rosinés, P. \& Hladun, N. L. (1996) Les especies saxícolo-calcícolas del grupo de Caloplaca lactea (Teloschistaceae, líquenes), en las regiones mediterranea y medioeuropea. Bulletin de la Société Linnéenne de Provence 47: 139-166.

Nimis, P. L. \& Martellos, S. (2008) ITALIC - The information system on Italian lichens. Version 4.0. University of Trieste, Deptartment of Biology, IN4.0/1. http://dbiodbs.univ.trieste.it/, Accessed 4 February 2013.

Nimis, P. L., Seaward, M. R. D., Ariño, X. \& Barreno, E. (1998) Lichen-induced chromatic changes on monuments: a case-study on the Roman amphitheater of Italica (S. Spain). Plant Biosystems 132: 5361.

Nylander, W. (1878) Symbolae quaedam ad lichenographiam Sahariensem. Flora (Regensburg) 61: 337-345.

Peksa, O. \& Škaloud, P. (2008) Changes in chloroplast structure in lichenized algae. Symbiosis 46: 153160.

Poelt, J. (1953a) Mitteleuropäische Flechten. I. Mitteilungen der Botanischen Staatssammlung München 1: 323-332.

Poelt, J. (1953b) Mitteleuropäische Flechten II. Mitteilungen der Botanischen Staatssammlung München 1: $230-238$.

Poelt, J. (1954) Die gelappten Arten der Flechtengattung Caloplaca in Europa mit besonderer Berücksichtigung Mitteleuropas. Mitteilungen der Botanischen Staatssammlung München 2: 11-31.

Poelt, J. (1955) Die Gipfelvegetation und -flora des Wettersteingebirges. Feddes Repertorium 58: 157-179.

Poelt, J. (1960) Mitteleuropäische Flechten VI. Mitteilungen der Botanischen Staatssammlung München 3: 568-584.

Poelt, J. (1964) Mitteleuropäische Flechten VIII. Mitteilungen der Botanischen Staatssammlung München 5: $247-265$

Poelt, J. (1975) Mitteleuropäische Flechten X. Mitteilungen der Botanischen Staatssammlung München 12: $1-32$.

Ronquist, F. \& Huelsenbeck, J. P. (2003) MRBAYES 3: Bayesian phylogenetic inference under mixed models. Bioinformatics 19: 1572-1574.

Roux, C. (1978) Complément à l'étude écologique et phytosociologique des peuplements lichéniques saxicoles-calcicoles du SE de la France. Bulletin du Musée d'Histoire Naturelle de Marseille 38: 65-185.

Roux, C. (1982) Lichens observés lors de la 8e session extraordinaire de la Société botanique du CentreOuest en Provence occidentale. Bulletin de la Société Botanique de Centre-Ouest, Nouvelle Série 13: 210 228.

Roux, C. (1984) Premier aperçu de la flore et de la végétation lichénique de la moyenne et haute vallée du Var. Bulletin de la Société linnéenne de Provence 35: 75-93.
Roux, C. \& Gueidan, C. (2002) Flore et végétation des lichens et champignons lichénicoles non lichénisés du massif de la Sainte-Baume (Var, Provence, France). Bulletin de la Société Linnéenne de Provence 53: $123-150$.

Schwarz, G. E. (1978) Estimating the dimension of a model. Annals of Statistics 6: 461-464.

Smith, C. W., Aptroot, A., Coppins, B. J., Fletcher, A., Gilbert, O. L., James, P. W. \& Wolseley, P. A. eds (2009) The Lichens of Great Britain and Ireland. London: British Lichen Society.

Søchting, U. (1997) Two major anthraquinone chemosyndromes in Teloschistaceae. Bibliotheca Lichenologica 68: $135-144$.

Søchting, U. \& Stordeur, R. (2001) Caloplaca thuringiaca sp. nov., a species from the Caloplaca holocarpa complex. Lichenologist 33: 467-472.

Søchting, U., Lorentsen, L. B. \& Arup, U. (2008) The lichen genus Caloplaca (Ascomycota, Lecanoromycetes) on Svalbard. Notes and additions. Nova Hedwigia 87: 69-96.

Šoun, J., Vondrák, J., Søchting, U., Hrouzek, P., Khodosovtsev, A. \& Arup, U. (2011) Taxonomy and phylogeny of the Caloplaca cerina group in Europe. Lichenologist 43: 113-135.

Svoboda, D., Czarnota, P., Bouda, F., Halda, J. P., Liška, J., Kukwa, M., Müller, A., Palice, Z., Peksa, O., Šoun, J. et al. (2007) Lichens recorded during 13th Spring Meeting of the Bryological and Lichenological Section ČBS on excursions in Bílé Karpaty Mts. and in other localities in SE Moravia. Bryonora 39: 39-49 [in Czech].

Tanabe, A. S. (2011) Kakusan4 and Aminosan: two programs for comparing nonpartitioned, proportional and separate models for combined molecular phylogenetic analyses of multilocus sequence data. Molecular Ecology Resources 11: 914-921.

Vězda, A. (1978) Neue oder wenig bekannte Flechten in der Tschechoslowakei. II. Folia Geobotanica et Phytotaxonomica 13: 397-420.

Vogel, S. (1955) Niedere "Fensterpflanzen" in der südafrikanischen Wüste. Eine ökologische Schilderung. Beiträge zur Biologie der Pflanzen 31: 45-135.

Vondrák, J. \& Hrouzek, P. (2006) Caloplaca soralifera, a new species from Europe. Graphis Scripta 18: 6-15.

Vondrák, J. \& Kubásek, J. (2013) Algal stacks and fungal stacks as adaptations to high light in lichens. Lichenologist 45: 115-124.

Vondrák, J. \& Wirth, V. (2013) Caloplaca. In Die Flechten Deutschlands (V. Wirth, M. Hauck \& M. Schultz, eds): 262-317. Stuttgart: Ulmer.

Vondrák, J., Kocourková, J., Palice, Z. \& Liška, J. (2007) New and noteworthy lichens in the Czech Republic - genus Caloplaca. Preslia 79: 163-184.

Vondrák, J., Šoun, J., Hrouzek, P., Ŕíha, P., Kubásek, J., Palice, Z. \& Søchting, U. (2008) Caloplaca subalpina and $C$. thracopontica, two new saxicolous species from the Caloplaca cerina group (Teloschistaceae). Lichenologist 40: 375-386.

Vondrák, J., Ríha, P., Arup, U. \& Søchting, U. (2009a) The taxonomy of the Caloplaca citrina group (Teloschistaceae) in the Black Sea region; with contribu- 
tions to the cryptic species concept in lichenology. Lichenologist 41: 571-604.

Vondrák, J., Šoun, J., Arup, U., Aptroot, A. \& Redchenko, O. (2009b) Caloplaca ulcerosa, a maritime species in Europe with a remarkable occurrence in the Czech Republic. Bryonora 44: 1-7.

Vondrák, J., Halda, J. P., Malíček, J. \& Müller, A. (2010a) Lichens recorded during the spring bryolichenological meeting in Chřiby Mts (Czech Republic), April 2010. Bryonora 45: 36-42.

Vondrák, J., Šoun, J., Sogaard, M., Søchting, U. \& Arup, U. (2010b) Caloplaca phlogina, a lichen with two facies; an example of infraspecific variability resulting in the description of a redundant species. Lichenologist 42: 685-692.

Vondrák, J., Ríha, P., Redchenko, O., Vondráková, O., Hrouzek, P. \& Khodosovtsev, A. (2011) The Caloplaca crenulatella species complex; its intricate taxonomy and description of a new species. Lichenologist 43: 467-481.

Vondrák, J., Halıc1, M. G., Kocakaya, M. \& Vondráková, O. (2012a) Teloschistaceae (lichenized Ascomycetes) in Turkey. 1. Some records from Turkey. Nova Hedwigia 94: 385-396.

Vondrák, J., Šoun, J., Vondráková, O., Fryday, A. M., Khodosovtsev, A. \& Davydov, E. (2012b) Absence of anthraquinone pigments is paraphyletic and a phylogenetically unreliable character in the Teloschistaceae. Lichenologist 44: 401-418.

Vondrak, J., Frolov, I., Arup, U. \& Khodosovtsev, A. (2013) Methods for phenotypic evaluation of crustose lichens with emphasis on Teloschistaceae. Chornomorskiy Botanichniy Zhurnal 9 (in press).
Werner, O., Ros, R. M. \& Guerra, J. (2002) Direct amplification and $\mathrm{NaOH}$ extraction: two rapid and simple methods for preparing bryophyte DNA for polymerase chain reaction (PCR). Fournal of Bryology 24: 127-131.

Wetmore, C. M. (1994) The lichen genus Caloplaca in North and Central America with brown or black apothecia. Mycologia 86: 813-838.

Wetmore, C. M. (2004) The sorediate corticolous species of Caloplaca in North and Central America. Bryologist 107: 505-520.

Wetmore, C. M. (2009) New species of Caloplaca (Teloschistaceae) from North America. Bryologist 112: 379-386.

White, T. J., Bruns, T. D., Lee, S. \& Taylor, J. (1990) Amplification and direct sequencing of fungal ribosomal RNA genes for phylogenetics. In PCR Protocols: a Guide to Methods and Applications (M. A. Innis, D. H. Gelfand, J. J. Sninsky \& T. J. White, eds): 315-322. San Diego: Academic Press.

Wilk, K. \& Flakus, A. (2006) Four species of Caloplaca (Teloschistaceae, lichenized Ascomycota) new to Poland. Mycotaxon 96: 61-71.

Wirth, V., Vondrák, J., de Bruyn, U. \& Hauck, M. (2011) Erstnachweise von Flechtenarten für Deutschland und Frankreich. Herzogia 24: 155-158.

Zhou G.-L., Zhao, Z.-T., Lü, L., Tong, D.-B., Ma, M.-M. \& Wang, H.-Y. (2012) Seven dark fruiting lichens of Caloplaca from China. Mycotaxon 122: 307-324. 